\title{
Dinuclear Fe(III) Hydroxypropyl-appended Macrocyclic Complexes as MRI
}

\section{Probes}

Didar Asik, ${ }^{1}$ Samira M. Abozeid, ${ }^{1}$ Steven G. Turowski, ${ }^{2}$ Joseph A. Spernyak ${ }^{2}$ and Janet R. Morrow $^{1^{*}}$

1 Department of Chemistry, University at Buffalo, State University of New York, Amherst, New York 14260, United States

2 Department of Cell Stress Biology, Roswell Park Comprehensive Cancer Center, New York 14263 United States

Contents

Page

Table of Contents

$\mathrm{S} 1$

Characterization of the Fe(III) Complexes

$\mathrm{S} 2-\mathrm{S} 8$

Effective Magnetic Moment

S9

MS analysis of $\mathrm{Fe}(\mathrm{TOB})$ formation

S9-S10

$\mathrm{pH}$ Potentiometric Titrations

S11-S13

UV-Vis Spectra - Kinetic inertness

S14-S18

Variable temperature ${ }^{17} \mathrm{O}$ NMR spectra for $\mathrm{Fe}(\mathrm{CDTA})$

S19

Proton relaxivity of iron complexes

S20-S22

HSA binding Isotherms and $\mathrm{K}_{d}$ Values

S23

Pharmacokinetic data for $\mathrm{Fe}_{2}$ (PARA)

S24

Chemical structures of the Fe(III) complexes

S25

References

S25 

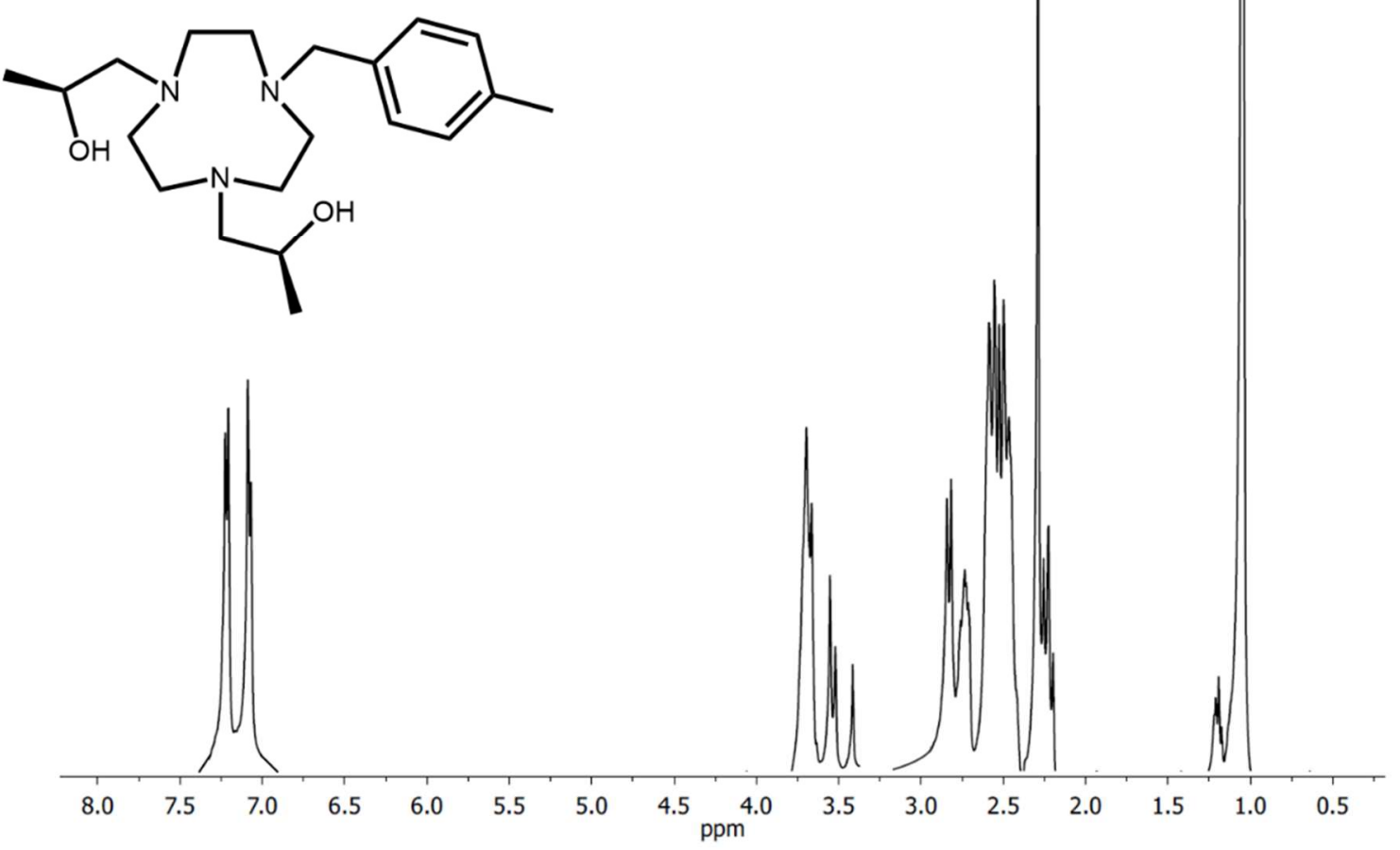

Figure S1. ${ }^{1} \mathrm{H}$ NMR spectrum of H-TOLPO $\left(500 \mathrm{MHz}, \mathrm{CDCl}_{3}, 298 \mathrm{~K}\right)$.

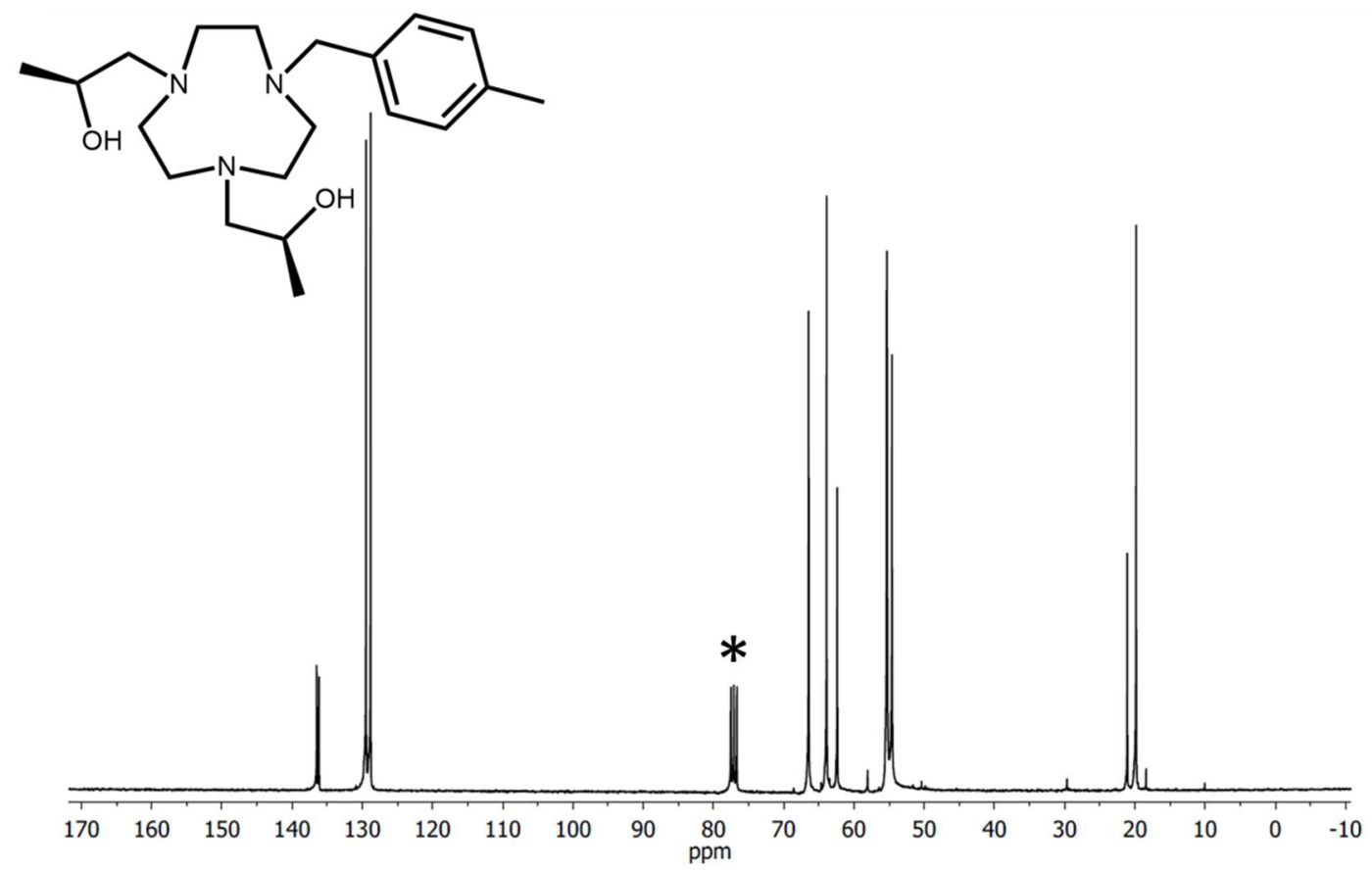

Figure S2. ${ }^{13} \mathrm{C}$ NMR spectrum of H-TOLPO (75 MHz, CDCl 3 -d, $298 \mathrm{~K}$ ). 


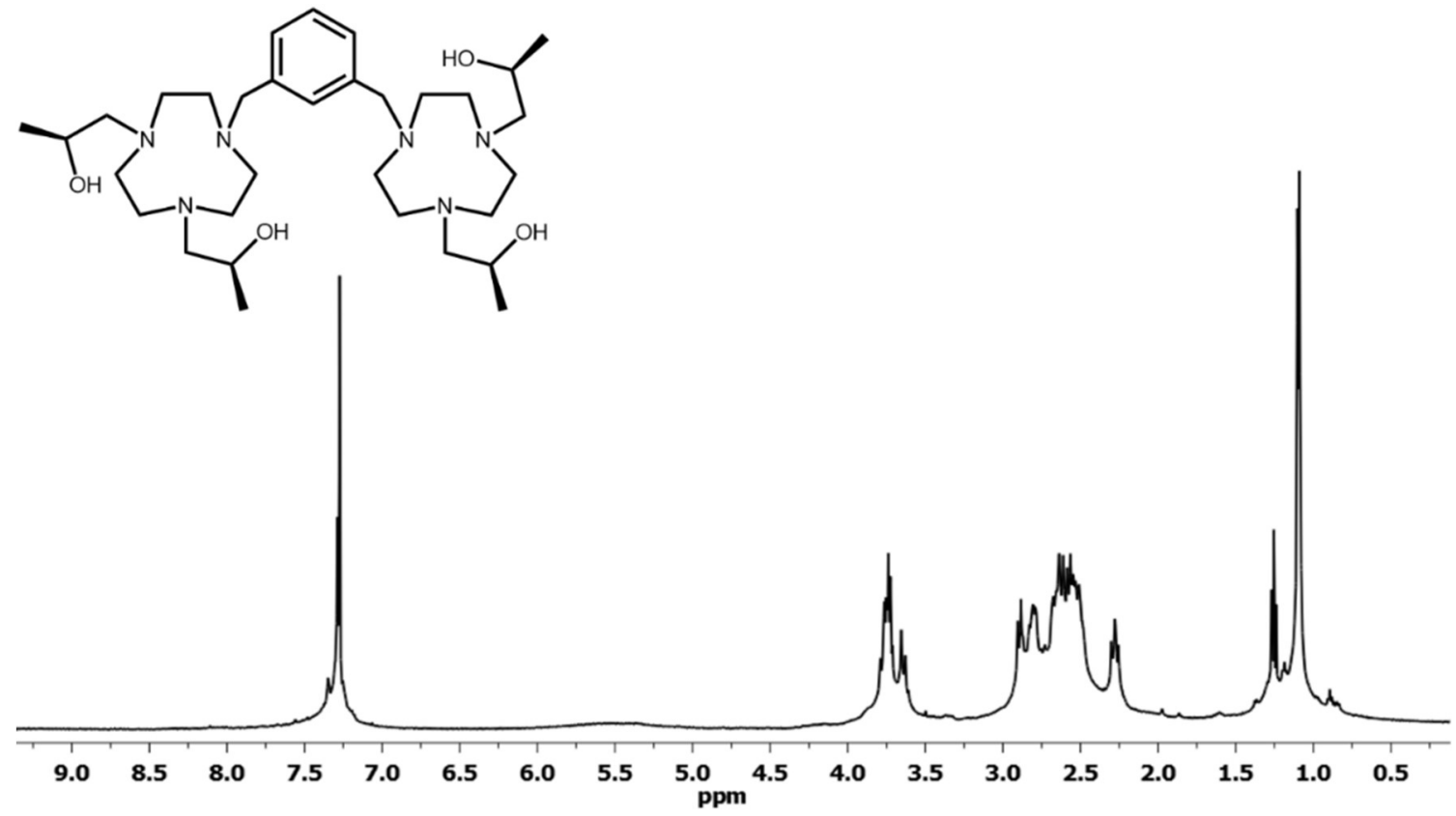

Figure S3. ${ }^{1} \mathrm{H}$ NMR spectrum of H-META $\left(500 \mathrm{MHz}, \mathrm{CDCl}_{3}, 298 \mathrm{~K}\right)$.

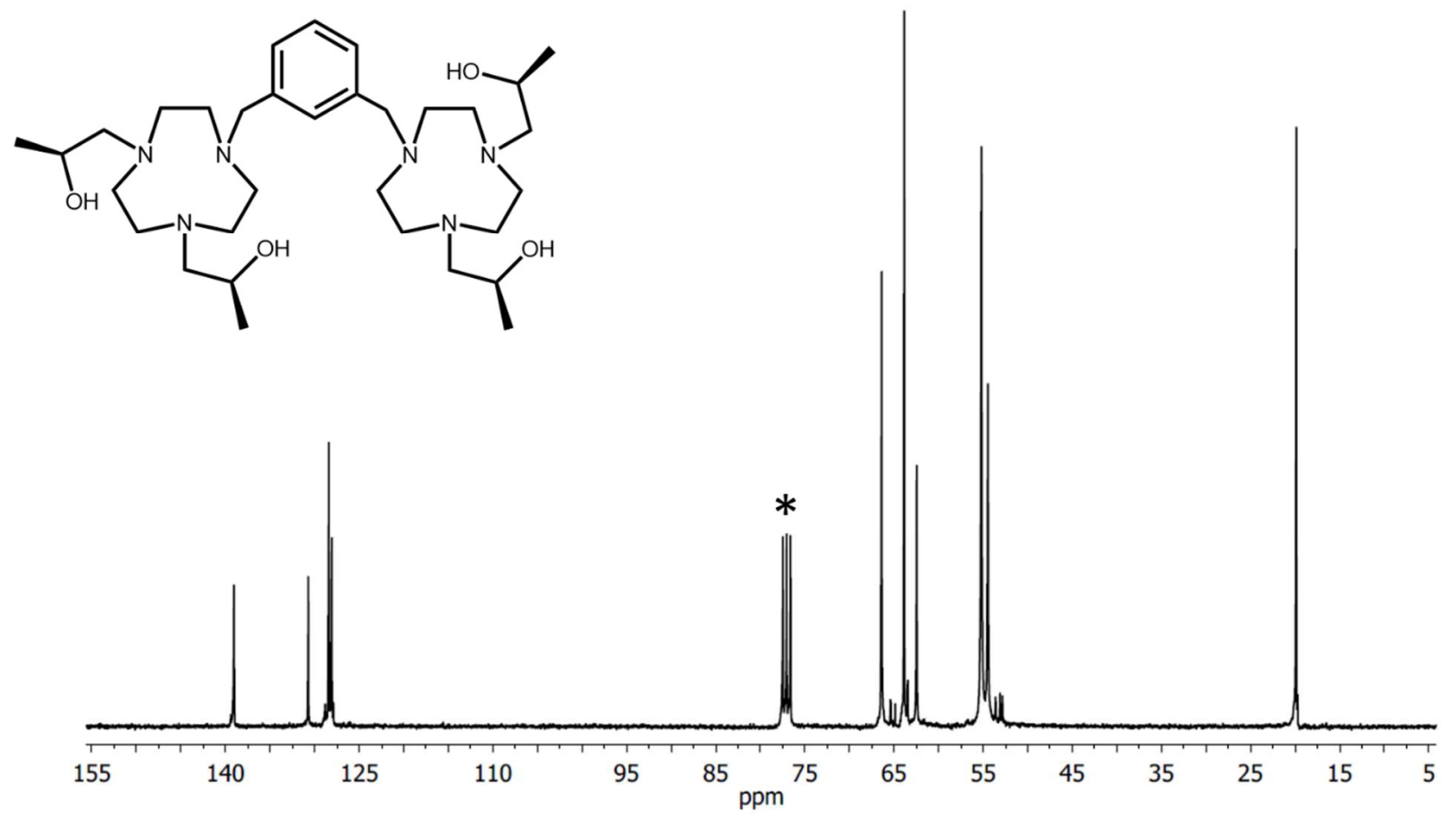

Figure S4. ${ }^{13} \mathrm{C}$ NMR spectrum of H-META $\left(75 \mathrm{MHz}, \mathrm{CDCl}_{3}-\mathrm{d}, 298 \mathrm{~K}\right)$. 


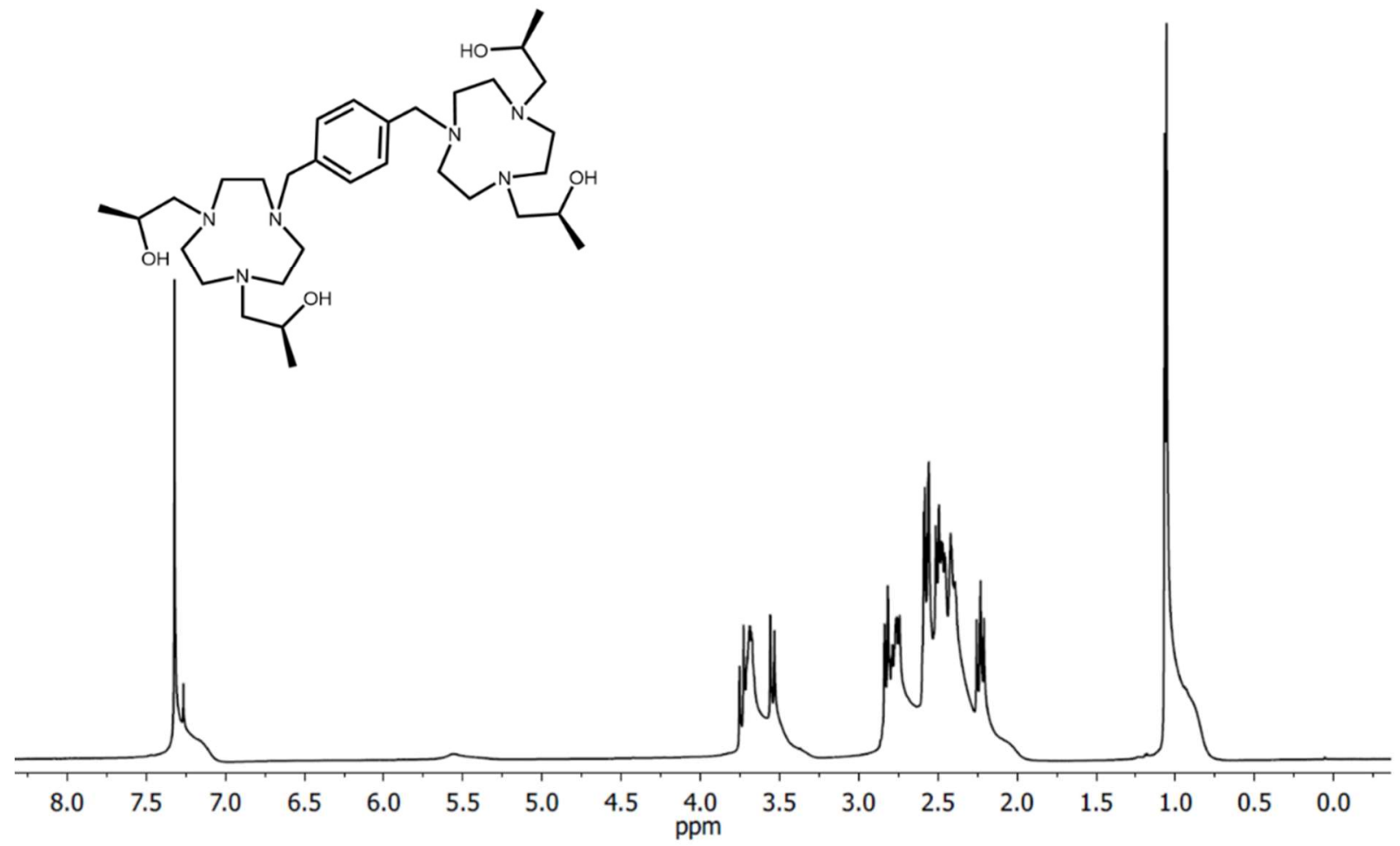

Figure S5. ${ }^{1} \mathrm{H}$ NMR spectrum of H-PARA $\left(500 \mathrm{MHz}, \mathrm{CDCl}_{3}, 298 \mathrm{~K}\right)$.

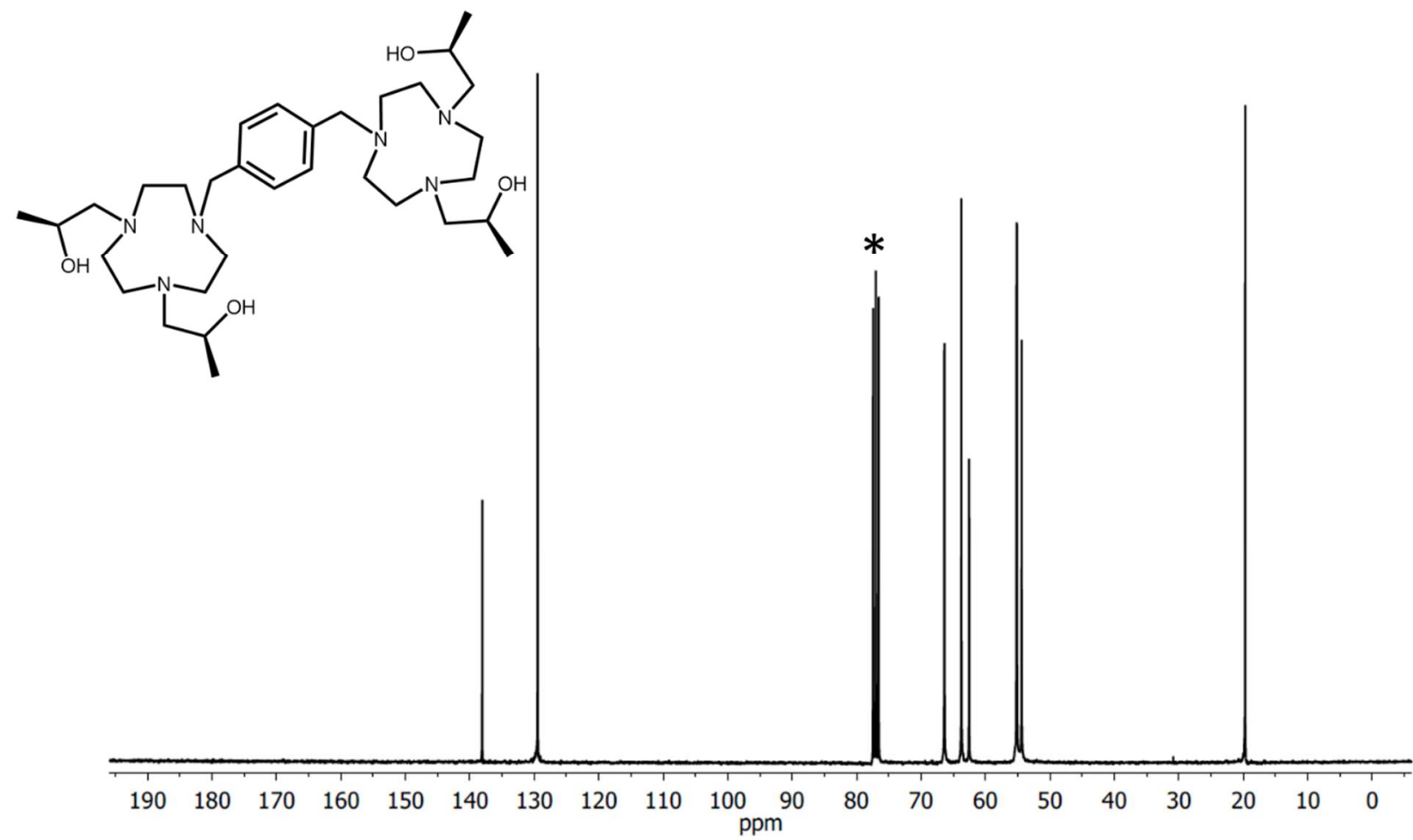

Figure S6. ${ }^{13} \mathrm{C}$ NMR spectrum of H-PARA $\left(75 \mathrm{MHz}, \mathrm{CHCl}_{3}-\mathrm{d}, 298 \mathrm{~K}\right)$. 


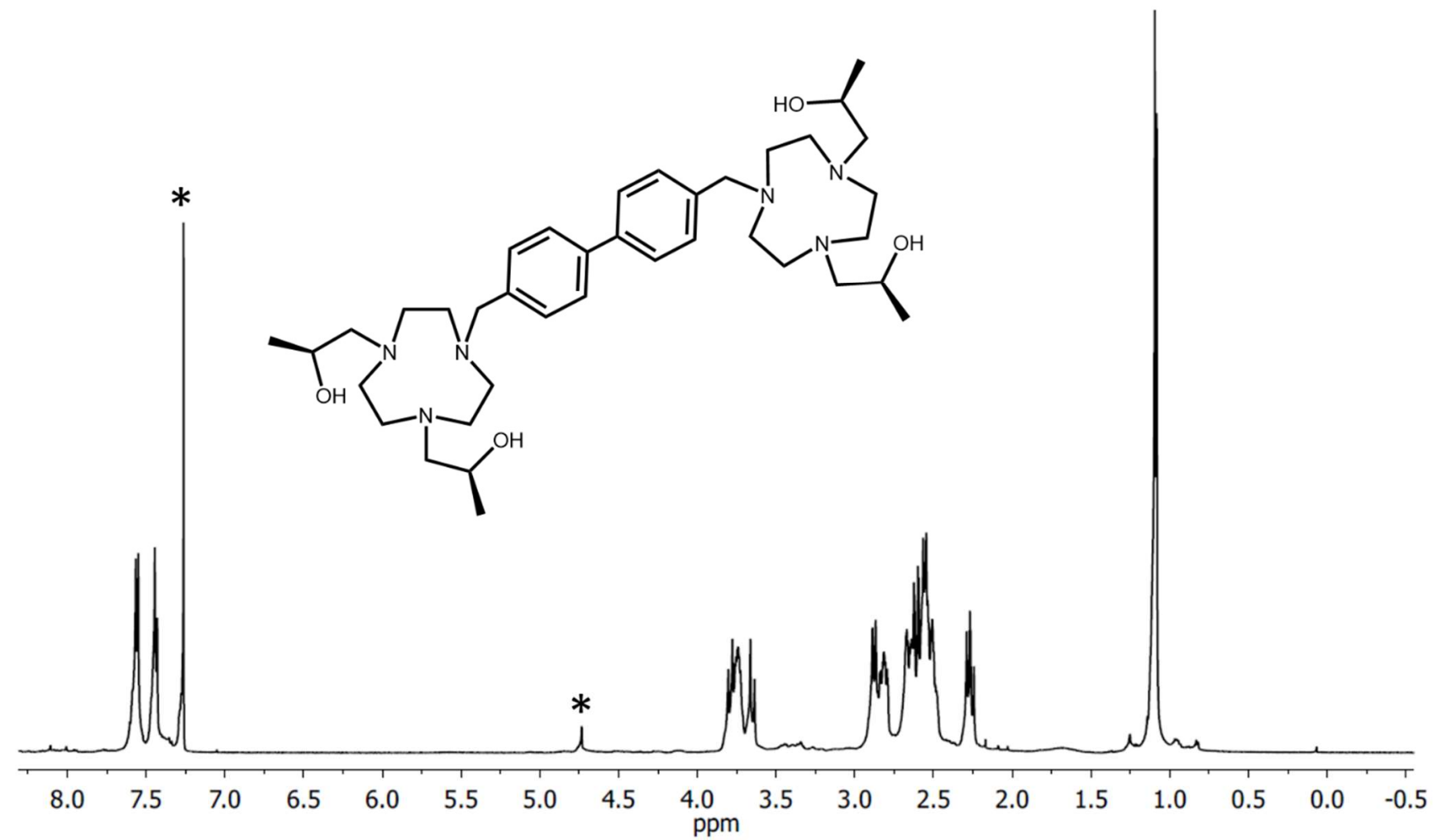

Figure S7. ${ }^{1} \mathrm{H}$ NMR spectrum of $\mathbf{H}-\mathrm{DIP}\left(500 \mathrm{MHz}, \mathrm{CDCl}_{3}, 298 \mathrm{~K}\right)$. 


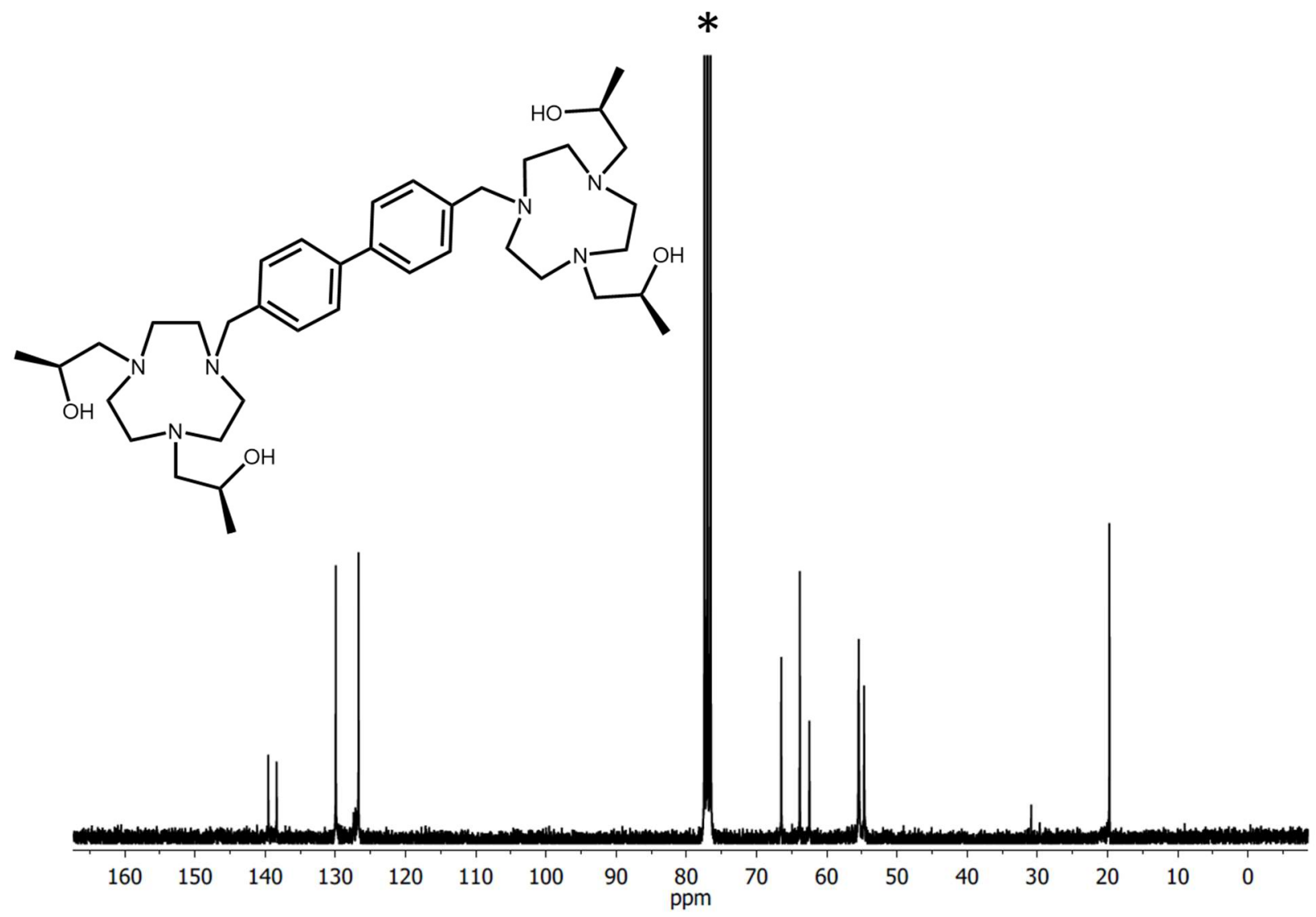

Figure S8. ${ }^{13} \mathrm{C}$ NMR spectrum of $\mathbf{H - D I P}\left(75 \mathrm{MHz}, \mathrm{CHCl}_{3}\right.$-d, $298 \mathrm{~K}$ ). 

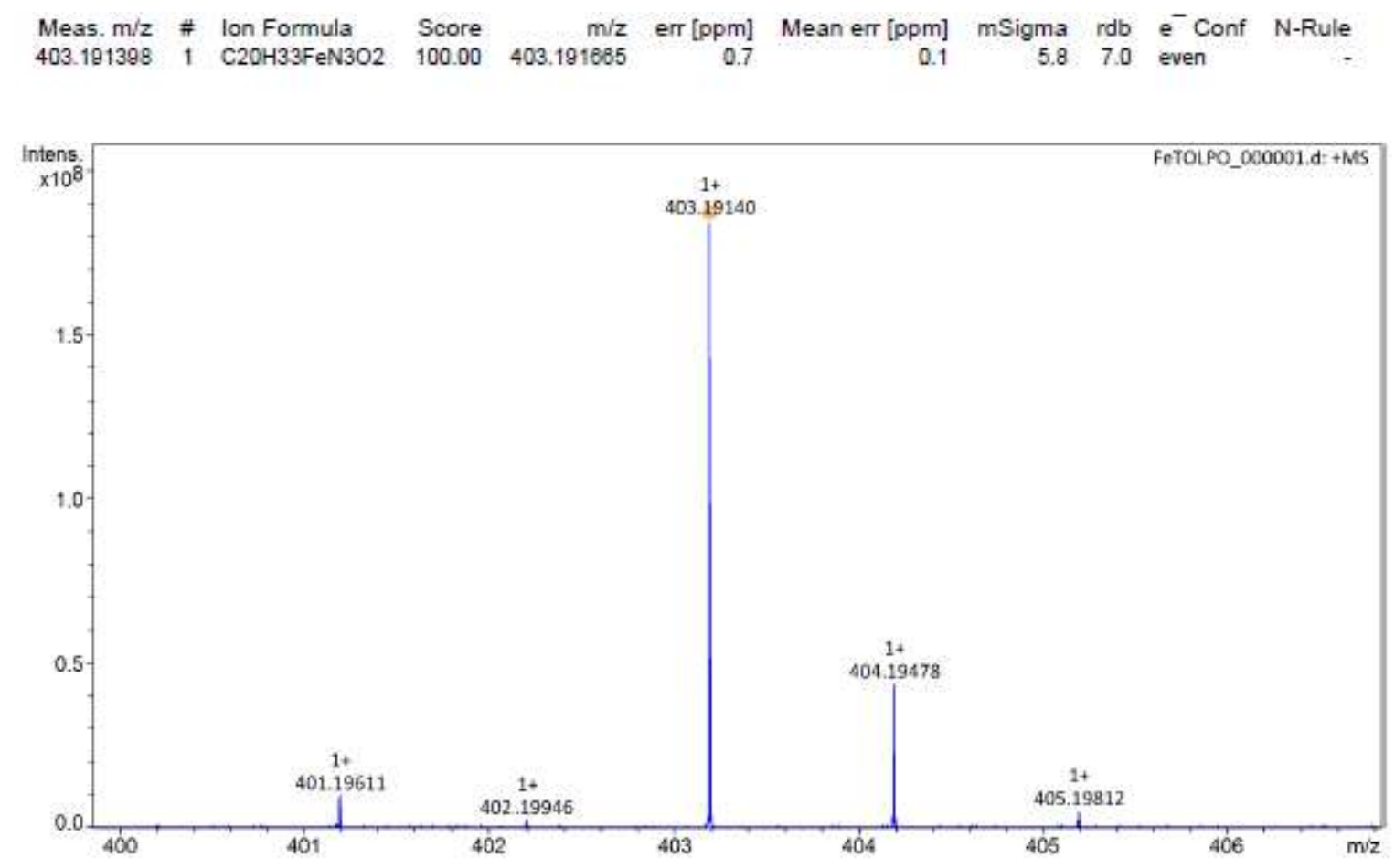

Figure S9. FT-ICR-MS spectrum of [Fe(TOLPO)Cl]Cl showing Fe(TOLPO)* as defined in Scheme 1

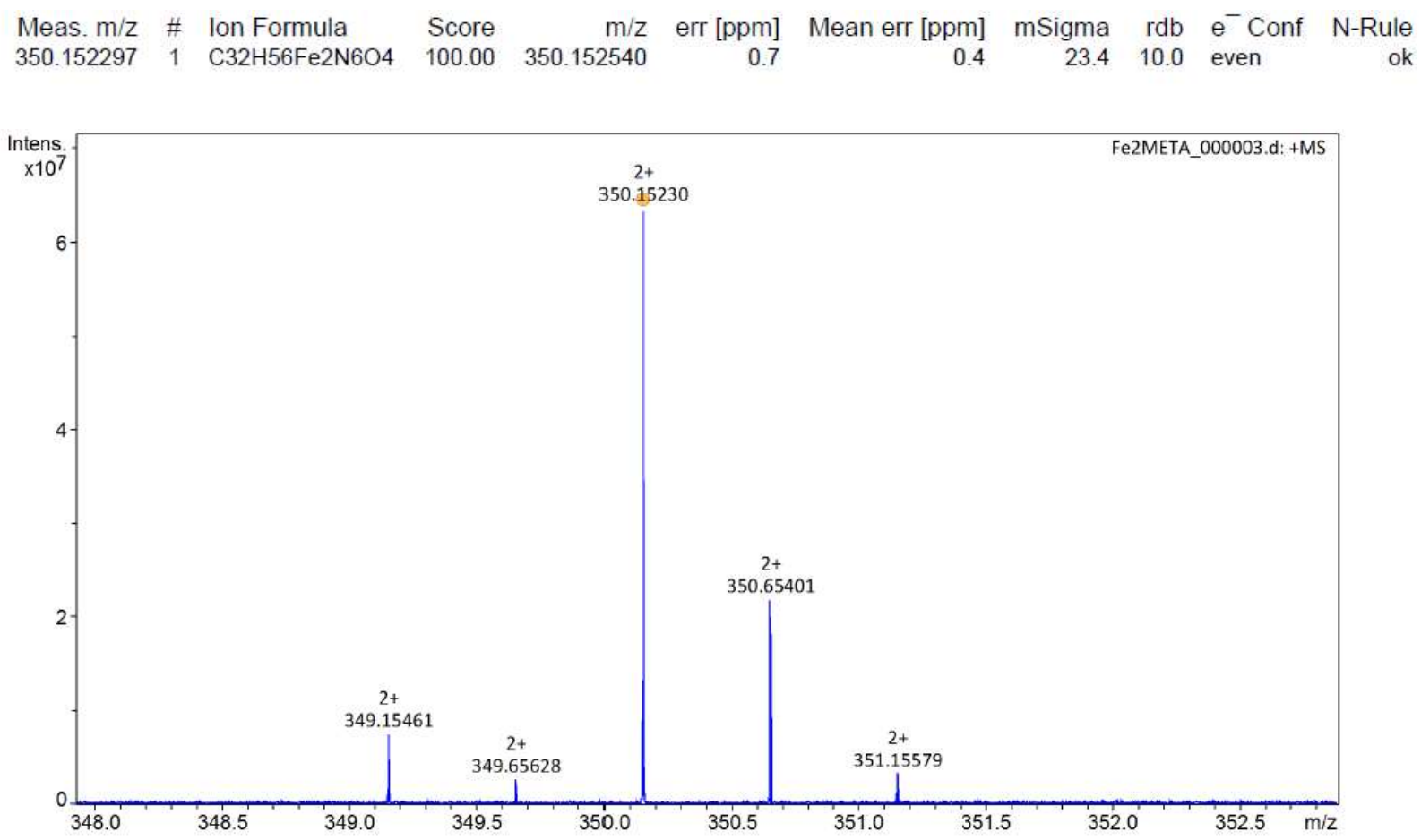

Figure S10. FT-ICR-MS spectrum of $\left[\mathrm{Fe}_{2}(\mathrm{META}) \mathrm{Cl}_{2}\right] \mathrm{Cl}_{2}$ showing peak for $\mathrm{Fe}_{2}(\mathrm{META}) *$ as defined in Scheme S1. 


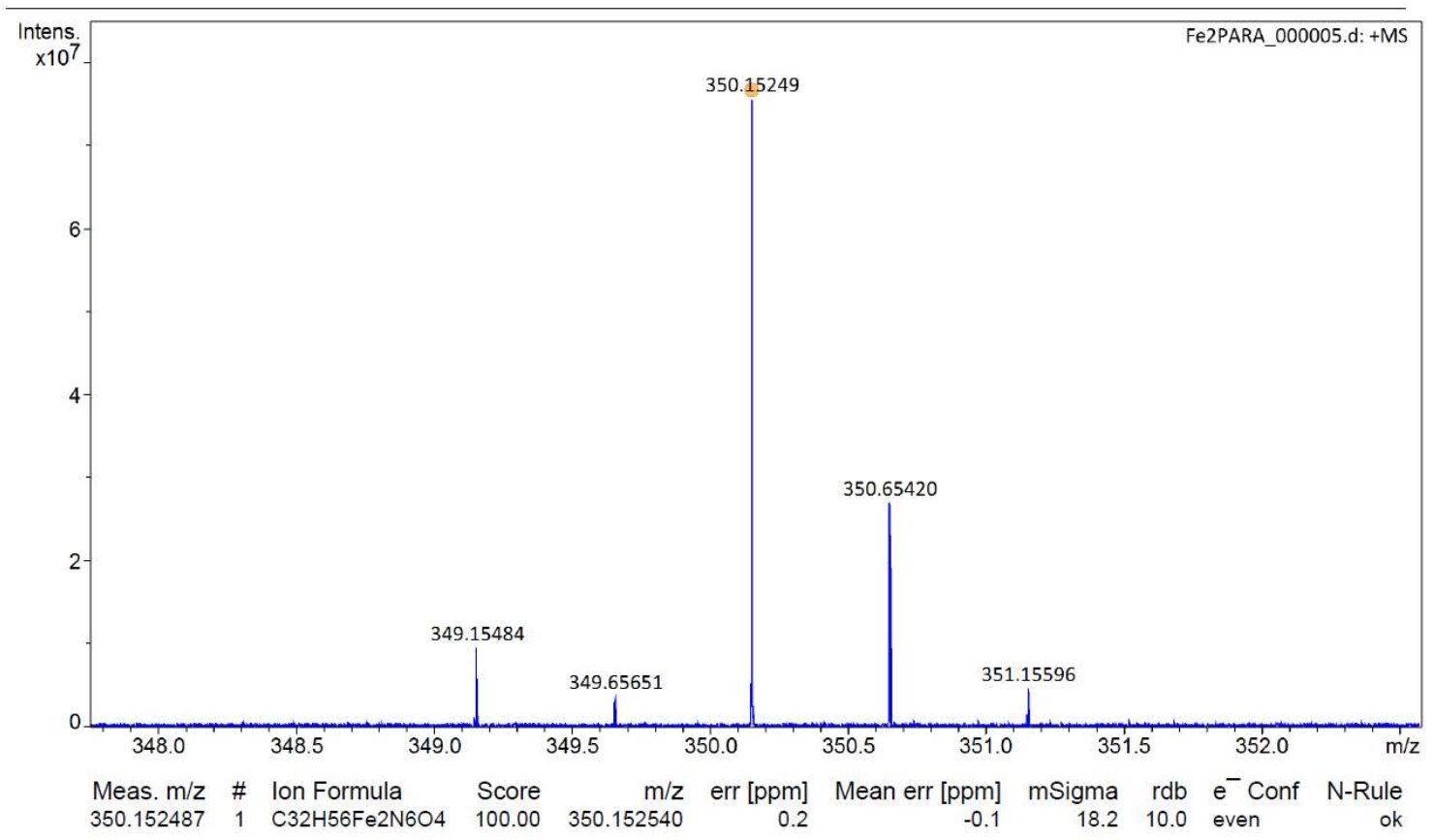

Figure S11. FT-ICR-MS spectrum of $\left[\mathrm{Fe}_{2}(\mathrm{PARA}) \mathrm{Cl}_{2}\right] \mathrm{Cl}_{2}$ showing peak for $\mathrm{Fe}_{2}(\mathrm{PARA}) *$ as defined in Scheme 1.
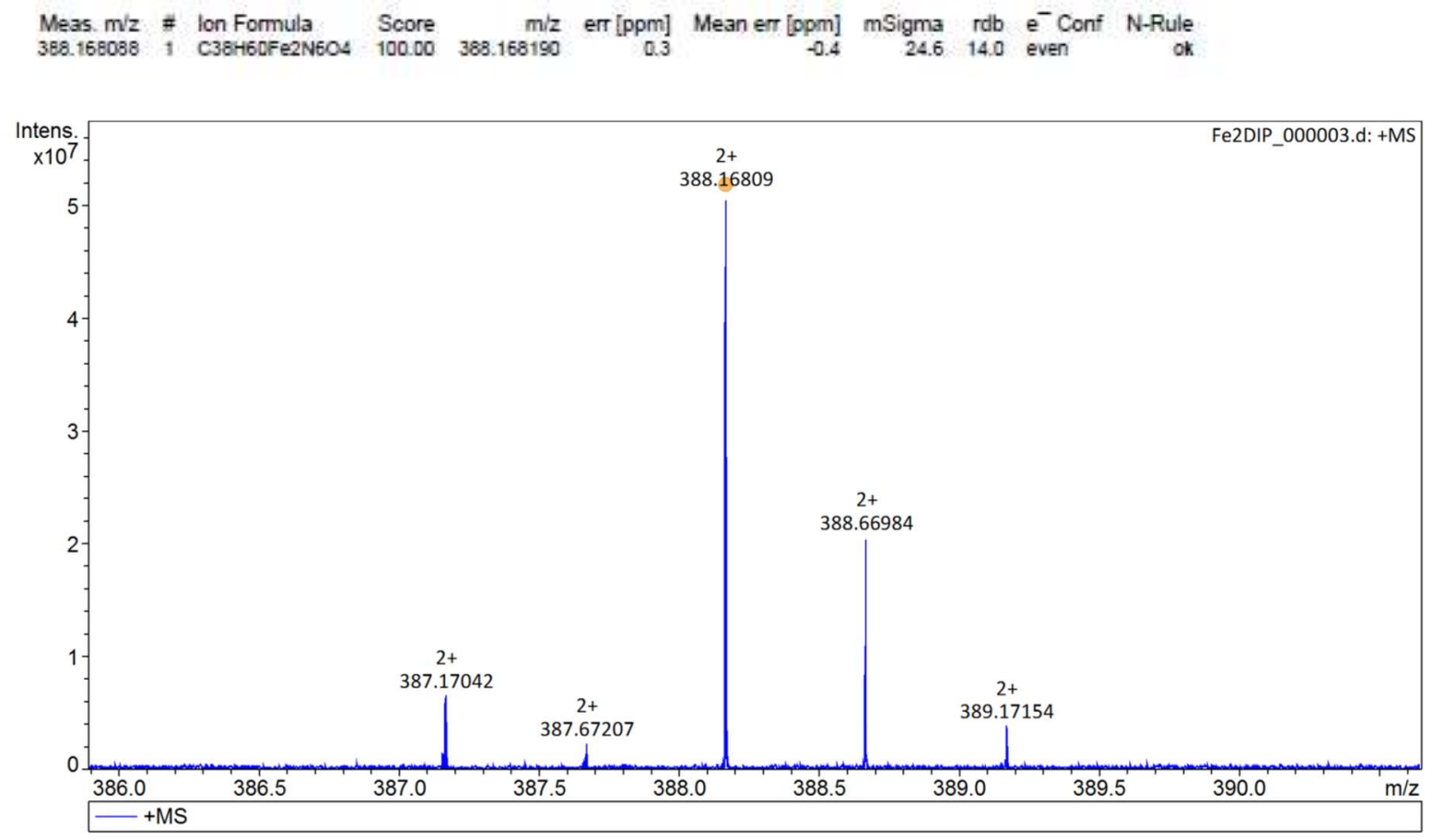

Figure S12. FT-ICR-MS spectrum of $\left[\mathrm{Fe}_{2}(\mathrm{DIP}) \mathrm{Cl}_{2}\right] \mathrm{Cl}_{2}$ showing peak for $\mathrm{Fe}_{2}(\mathrm{DIP})^{*}$ as defined in Scheme 1 
Table S.1. Effective magnetic moment values through Evans method for iron complexes

\begin{tabular}{cc}
\hline Complex & $\boldsymbol{\mu}_{\text {eff }}$ per iron \\
\hline $\mathrm{Fe}(\mathrm{TOB})$ & $5.9 \pm 0.8^{*}$ \\
$\mathrm{Fe}(\mathrm{TOLPO})$ & $5.6 \pm 0.05$ \\
$\mathrm{Fe}_{2}$ (META) & $5.6 \pm 0.04$ \\
$\mathrm{Fe}_{2}$ (PARA) & $5.6 \pm 0.04$ \\
$\mathrm{Fe}_{2}$ (DIP) & $5.5 \pm 0.06$ \\
\hline
\end{tabular}

*from reference ${ }^{1}$
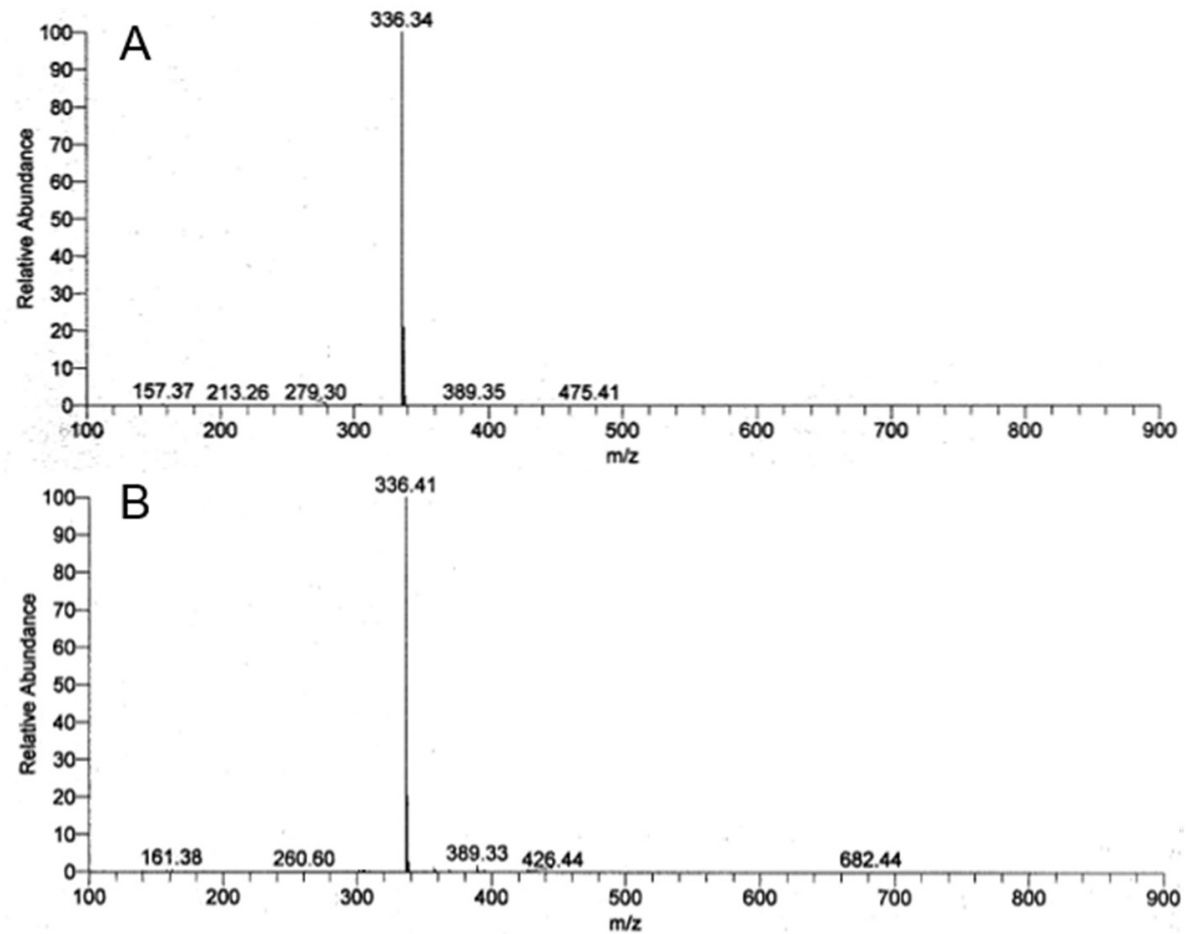

Figure S13. Analysis of a solution of $1 \mathrm{mM} \mathrm{H}-\mathrm{TOB}$ ligand and $1 \mathrm{mM} \mathrm{FeCl}_{3} \cdot 6 \mathrm{H}_{2} \mathrm{O}$, incubated at $\mathrm{pH} 3,25{ }^{\circ} \mathrm{C}$ by using ESI-MS. Spectra show only ligand (m/z): $336.34\left(\mathrm{M}+\mathrm{H}^{+}, 100 \%\right)$ and no formation of Fe(TOB) complex. (A) Scan after $1 \mathrm{hr}$. (B) Scan after $18 \mathrm{hr}$. 

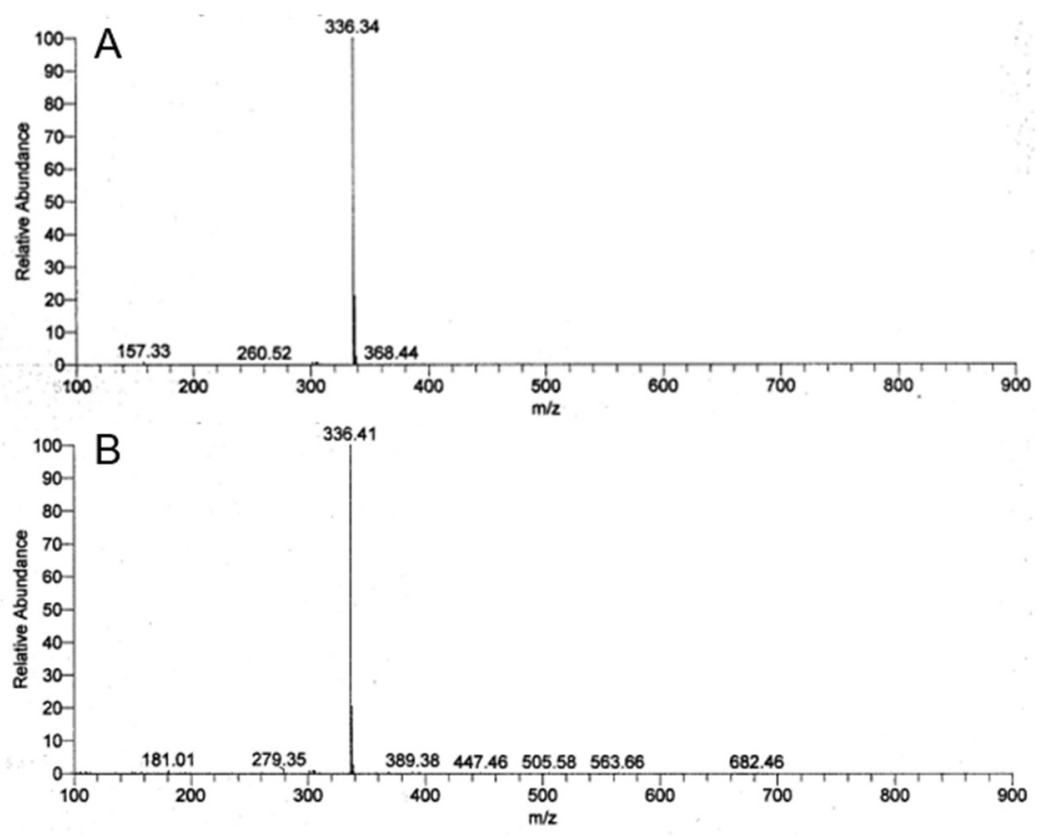

Figure S14. Analysis of a solution of $1 \mathrm{mM} \mathrm{H}-\mathrm{TOB}$ ligand and $1 \mathrm{mM} \mathrm{FeCl}{ }_{3} \cdot 6 \mathrm{H}_{2} \mathrm{O}$, incubated at pH 5, $25^{\circ} \mathrm{C}$ by using ESI-MS. Spectra show only ligand $(\mathrm{m} / \mathrm{z}): 336.34\left(\mathrm{M}+\mathrm{H}^{+}, 100 \%\right)$ and no formation of Fe(TOB) complex. (A) Scan after $1 \mathrm{hr}$. (B) Scan after $18 \mathrm{hr}$.
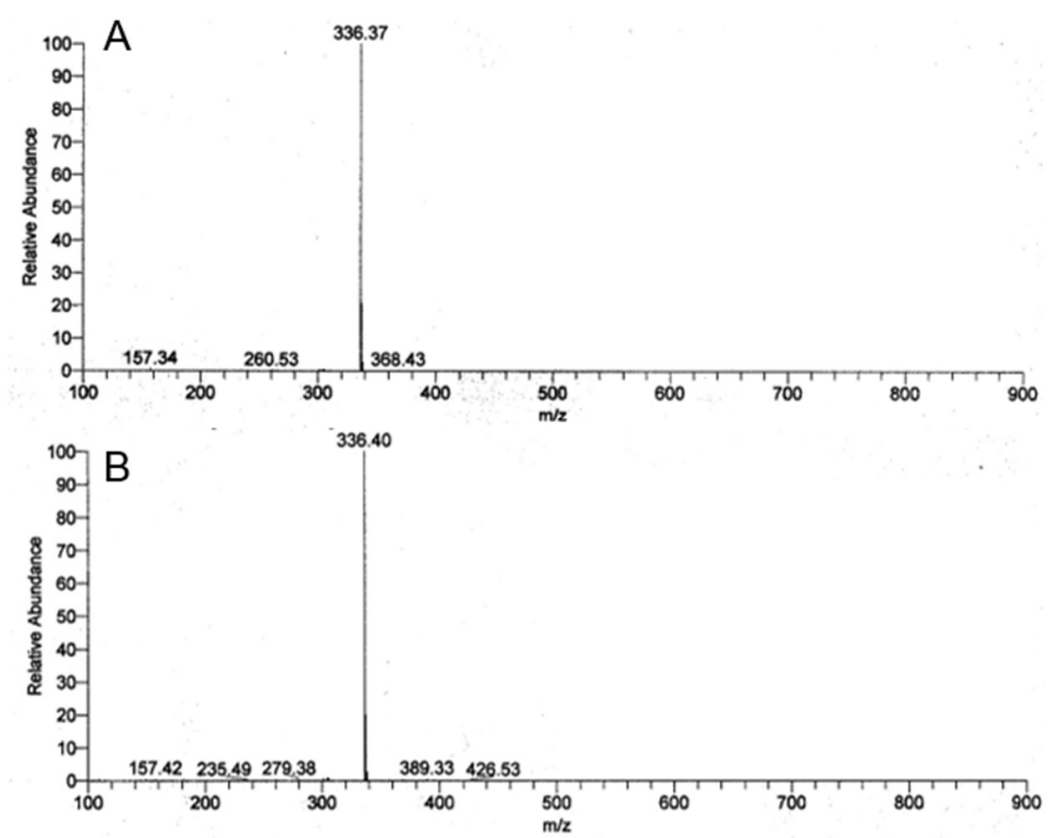

Figure S15. Analysis of a solution of $1 \mathrm{mM} \mathrm{H}-\mathrm{TOB}$ ligand and $1 \mathrm{mM} \mathrm{FeCl}{ }_{3} \cdot 6 \mathrm{H}_{2} \mathrm{O}$, incubated at $\mathrm{pH} 7,25^{\circ} \mathrm{C}$ by using ESI-MS. Spectra show only ligand $(\mathrm{m} / \mathrm{z}): 336.34\left(\mathrm{M}+\mathrm{H}^{+}, 100 \%\right)$ and no formation of Fe(TOB) complex. (A) Scan after $1 \mathrm{hr}$. (B) Scan after $18 \mathrm{hr}$. 
Table S.2. Equilibrium expressions for each constant in Table 1. Equations refer to the ionization of the Fe(III) complex and show the relations between the overall binding constant and the stepwise dissociation constant

\begin{tabular}{|l|l|l|l|}
\hline & Overall association constants & Stepwise association constants \\
\hline$A+H \leftrightarrow A H$ & $\beta_{11}=\frac{[A H]}{[A][H]}$, & $A+H \leftrightarrow A H$ & $K_{1}=\frac{[A H]}{[A][H]}$ \\
& $\log \beta_{11}=p K_{a 2}$ & & \\
\hline$A+2 H \leftrightarrow A H_{2}$ & $\beta_{12}=\frac{\left[A H_{2}\right]}{[A][H]^{2}}$, & $A H+H \leftrightarrow A H_{2}$ & $K_{2}=\frac{\left[A H_{2}\right]}{[A H][H]}$ \\
& $\log \beta_{12}=p K_{a 2}+p K_{a 1}$ & & \\
& & & \\
\hline
\end{tabular}

\section{$\beta:$ Overall binding constant}

\section{$K$ : Stepwise dissociation constant}

$$
\begin{aligned}
& A+H \leftrightarrow A H \\
& A+2 H \leftrightarrow A H_{2} \\
& \beta_{11}=\frac{[A H]}{[A][H]} \\
& \beta_{12}=\frac{\left[A H_{2}\right]}{[A][H]^{2}} \\
& \log \beta_{11}=p K_{a 2} \\
& \log \beta_{12}=p K_{a 2}+p K_{a 1} \\
& A+H \leftrightarrow A H \\
& A H+H \leftrightarrow A H_{2} \\
& K_{1}=\frac{[A H]}{[A][H]} \\
& K_{2}=\frac{\left[A H_{2}\right]}{[A H][H]}
\end{aligned}
$$



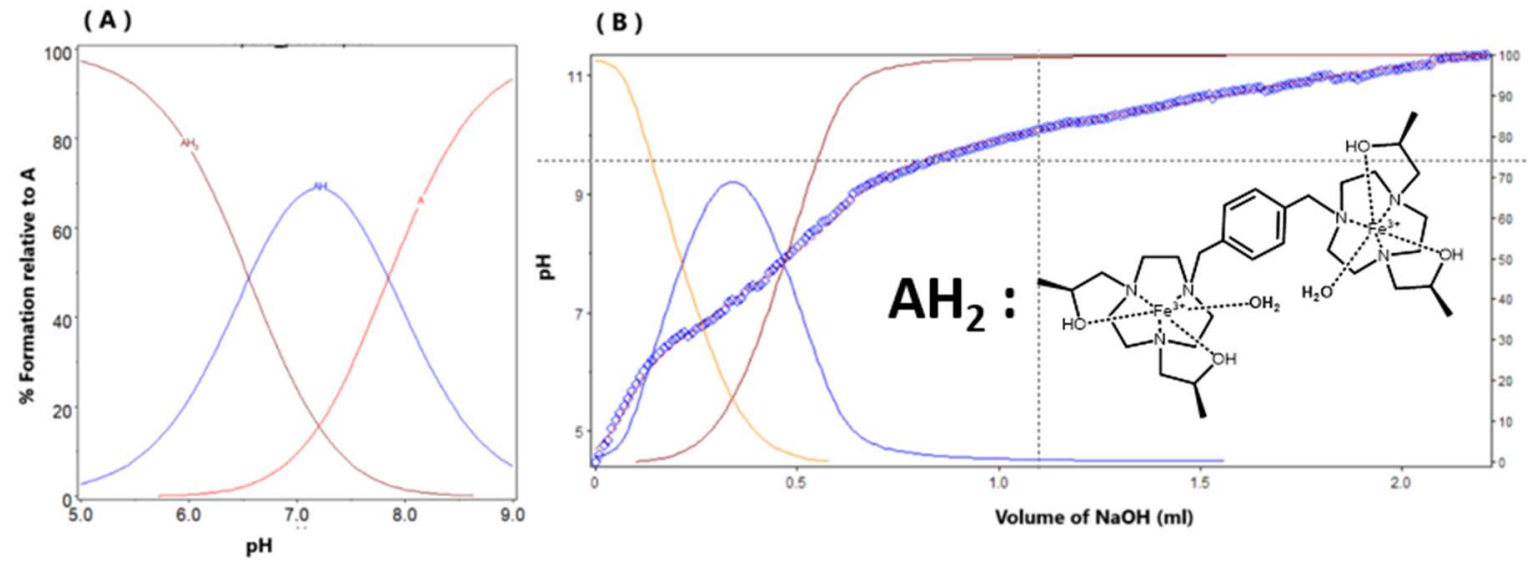

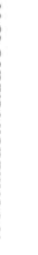

Figure S13. (A) Speciation diagram derived from potentiometric data to represent a solution containing $1.0 \mathrm{mM} \mathrm{Fe}$ (PARA) and $0.1 \mathrm{M} \mathrm{NaCl}$ at $37{ }^{\circ} \mathrm{C}$. $\mathbf{A H}_{2}$ represents the fully protonated complex $\mathrm{Fe}_{2}\left(\mathrm{PARA}+\mathrm{H}^{+}\right)$. (B) Titration curve with corresponding fit for determination of $\mathrm{K}_{1}$ and $\mathrm{K}_{2}$ values shown in Table 1 for $\mathrm{Fe}_{2}(\mathrm{PARA}) ;[\mathrm{NaOH}]=0.098838 \mathrm{M}$.
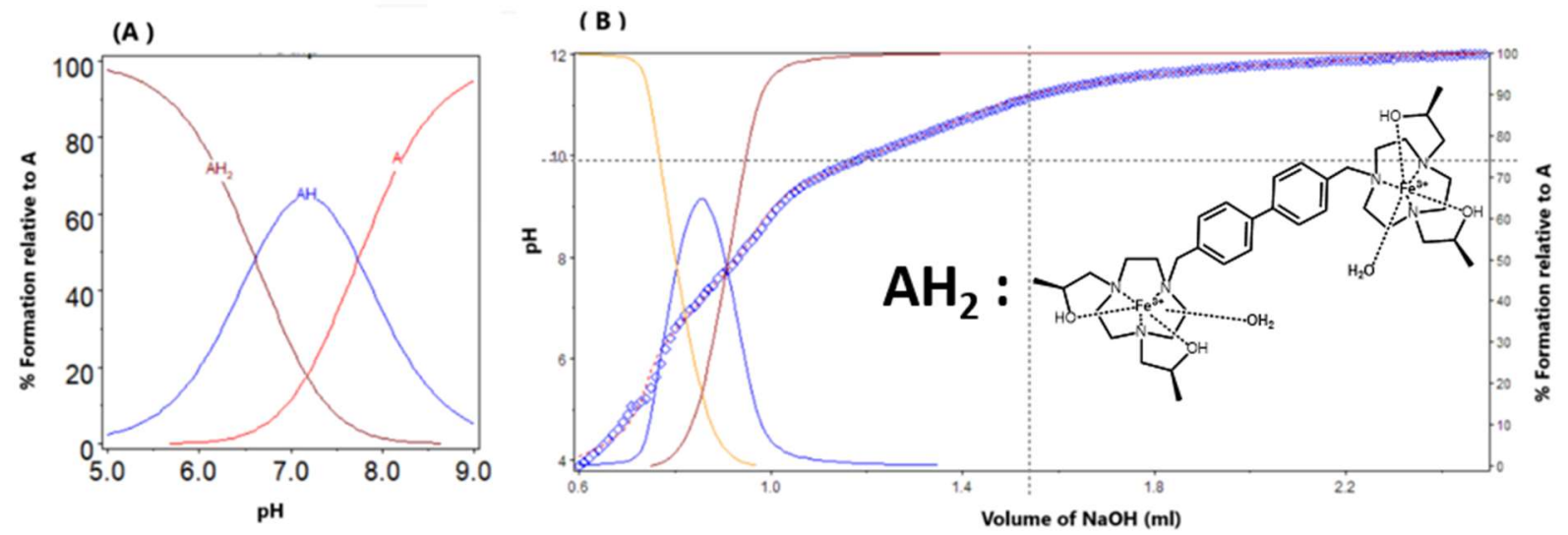

Figure S14. (A) Speciation diagram derived from potentiometric data to represent a solution containing $1.0 \mathrm{mM} \mathrm{Fe}_{2}$ (DIP) and $0.1 \mathrm{M} \mathrm{NaCl}$ at $37{ }^{\circ} \mathrm{C}$. $\mathbf{A H}_{2}$ represents the fully protonated complex $\mathrm{Fe}_{2}\left(\mathrm{DIP}+\mathrm{H}^{+}\right)$. (B) Titration curve with corresponding fit for determination of $\mathrm{K}_{1}$ and $\mathrm{K}_{2}$ values shown in Table 1 for $\mathrm{Fe}_{2}(\mathrm{DIP}) ;[\mathrm{NaOH}]=0.098838 \mathrm{M}$. 

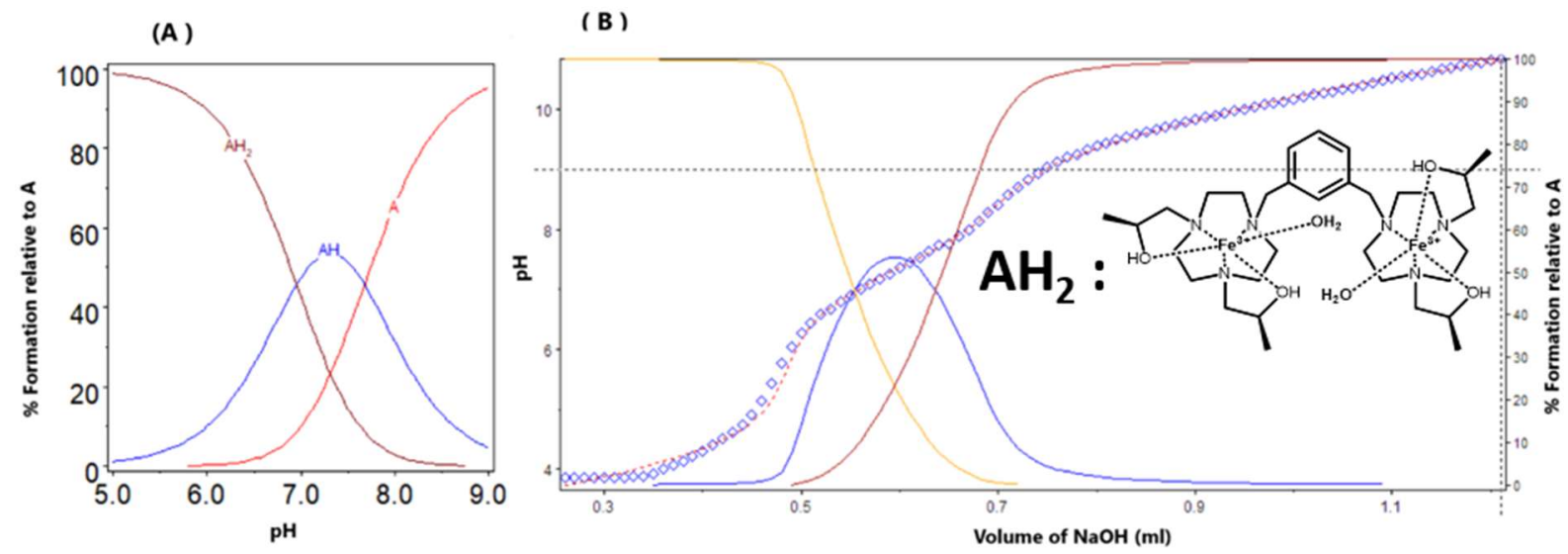

Figure S15. (A) Speciation diagram derived from potentiometric data to represent a solution containing $1.0 \mathrm{mM} \mathrm{Fe}$ (META) and $0.1 \mathrm{M} \mathrm{NaCl}$ at $37{ }^{\circ} \mathrm{C} . \mathbf{A H}_{2}$ represents the fully protonated complex $\mathrm{Fe}_{2}\left(\mathrm{META}+\mathrm{H}^{+}\right)$. (B) Titration curve with corresponding fit for determination of $\mathrm{K}_{1}$ and $\mathrm{K}_{2}$ values shown in Table 1 for $\mathrm{Fe}_{2}(\mathrm{META}) ;[\mathrm{NaOH}]=0.098838 \mathrm{M}$.

(A)

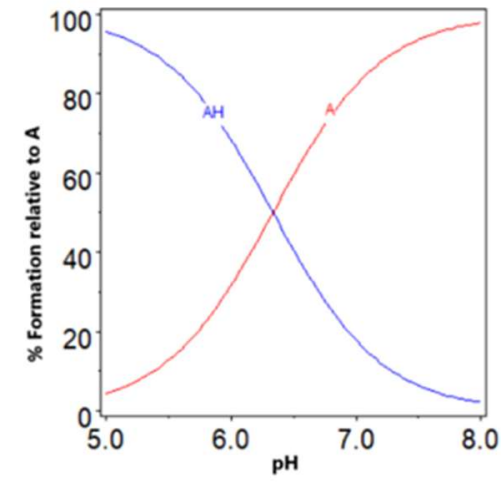

(B)

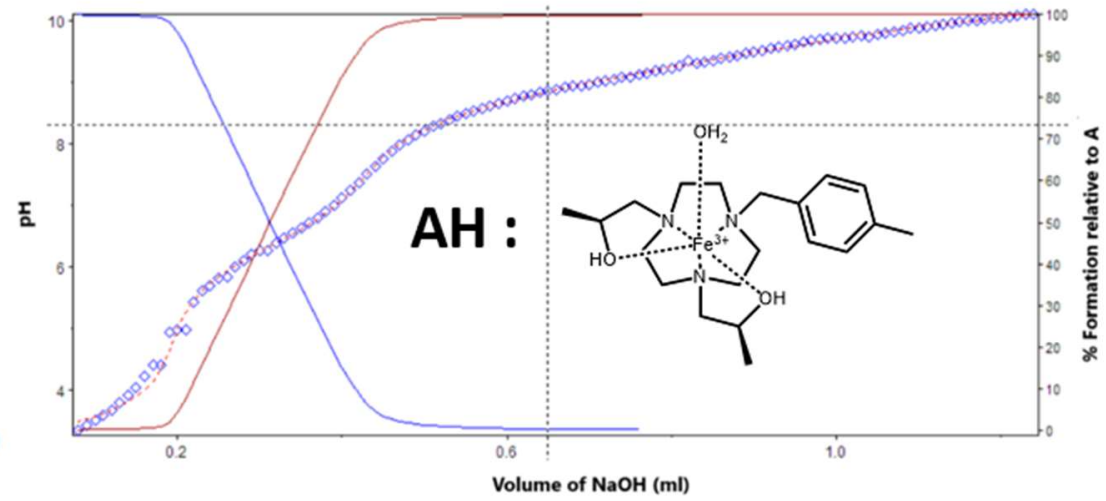

Figure S16. (A) Speciation diagram derived from potentiometric data to represent a solution containing $1.0 \mathrm{mM} \mathrm{Fe}(\mathrm{TOLPO})$ and $0.1 \mathrm{M} \mathrm{NaCl}$ at $37^{\circ} \mathrm{C}$. AH represents the fully protonated complex $\left(\mathrm{Fe}\left(\mathrm{TOLPO}+\mathrm{H}^{+}\right)\right.$. (B) Titration curve with corresponding fit for determination of $\mathrm{K}$ values shown in Table 1 for Fe(TOLPO); $[\mathrm{NaOH}]=0.098838 \mathrm{M}$. 

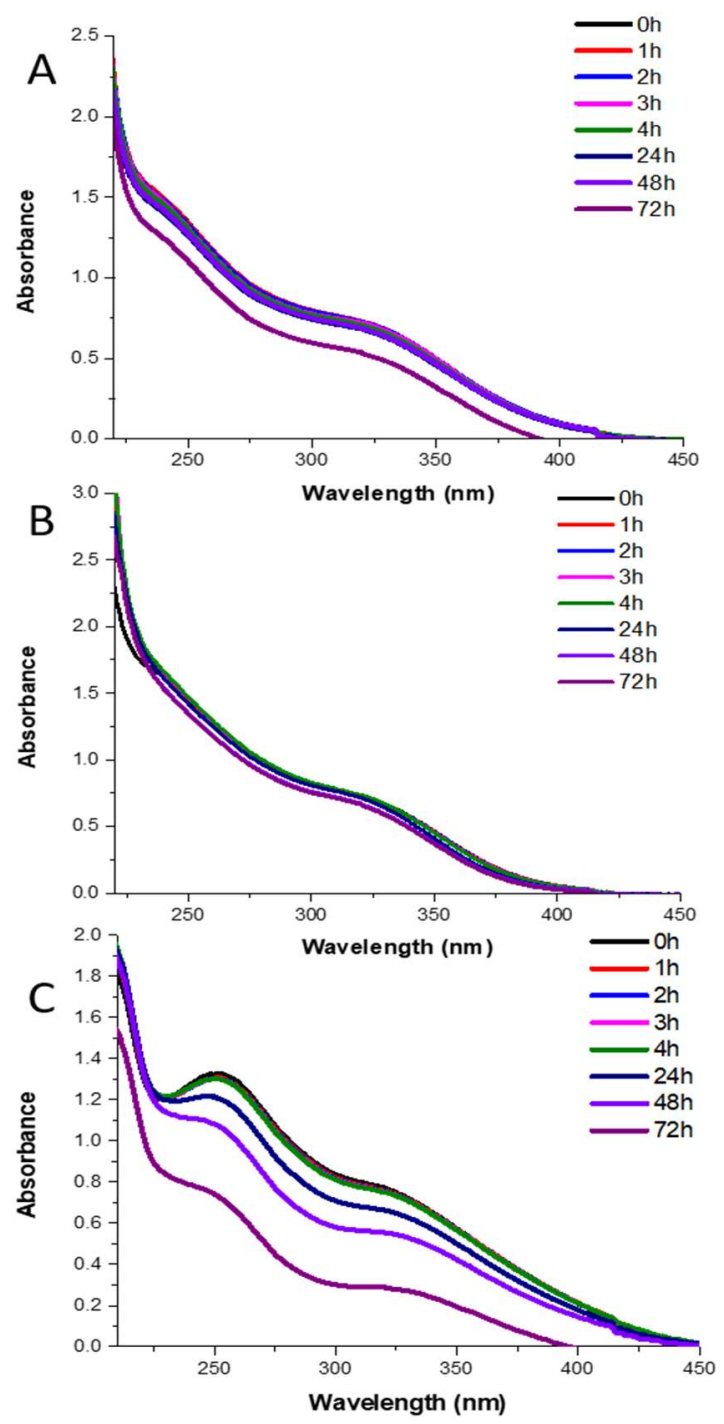

Figure S17. A) UV-vis spectra of $\mathrm{Fe}_{2}(\mathrm{META})$ were acquired over a $72 \mathrm{~h}$ time period at $37^{\circ} \mathrm{C}$. Solutions contained $200 \mathrm{uM} \mathrm{Fe}$ (META) and $10 \mathrm{mM}$ HEPES buffer at $7.2 \mathrm{pH}$. $\varepsilon(330 \mathrm{~nm})=3460$ $\mathrm{M}^{-1} \mathrm{~cm}^{-1}$. Dissociation after $72 \mathrm{~h}$ was $25.9 \%$. B) UV-vis spectra of Fe2(META) were acquired over a $72 \mathrm{~h}$ time period at $37^{\circ} \mathrm{C}$. Solutions contained $200 \mathrm{uM} \mathrm{Fe}$ (META), $25 \mathrm{mM} \mathrm{NaHCO} 3,0.50 \mathrm{mM}$ $\mathrm{Na}_{2} \mathrm{HPO}_{4}, 10 \mathrm{mM}$ HEPES buffer at $7.2 \mathrm{pH}$. $\varepsilon(330 \mathrm{~nm})=3531 \mathrm{M}^{-1} \mathrm{~cm}^{-1}$. Dissociation after $72 \mathrm{~h}$ was $11.2 \%$. C) $\mathrm{UV}$-vis spectra of $\mathrm{Fe}_{2}(\mathrm{META})$ were recorded over a $72 \mathrm{~h}$ time period at $37^{\circ} \mathrm{C}$. Solutions contained $200 \mathrm{uM} \mathrm{Fe} \mathrm{Fe} 2$ (META) dissolved in 0.1 M HCl. $\varepsilon(250 \mathrm{~nm})=6600 \mathrm{M}^{-1} \mathrm{~cm}^{-1}, \varepsilon(330 \mathrm{~nm})=$ $3780 \mathrm{M}^{-1} \mathrm{~cm}^{-1}$. 


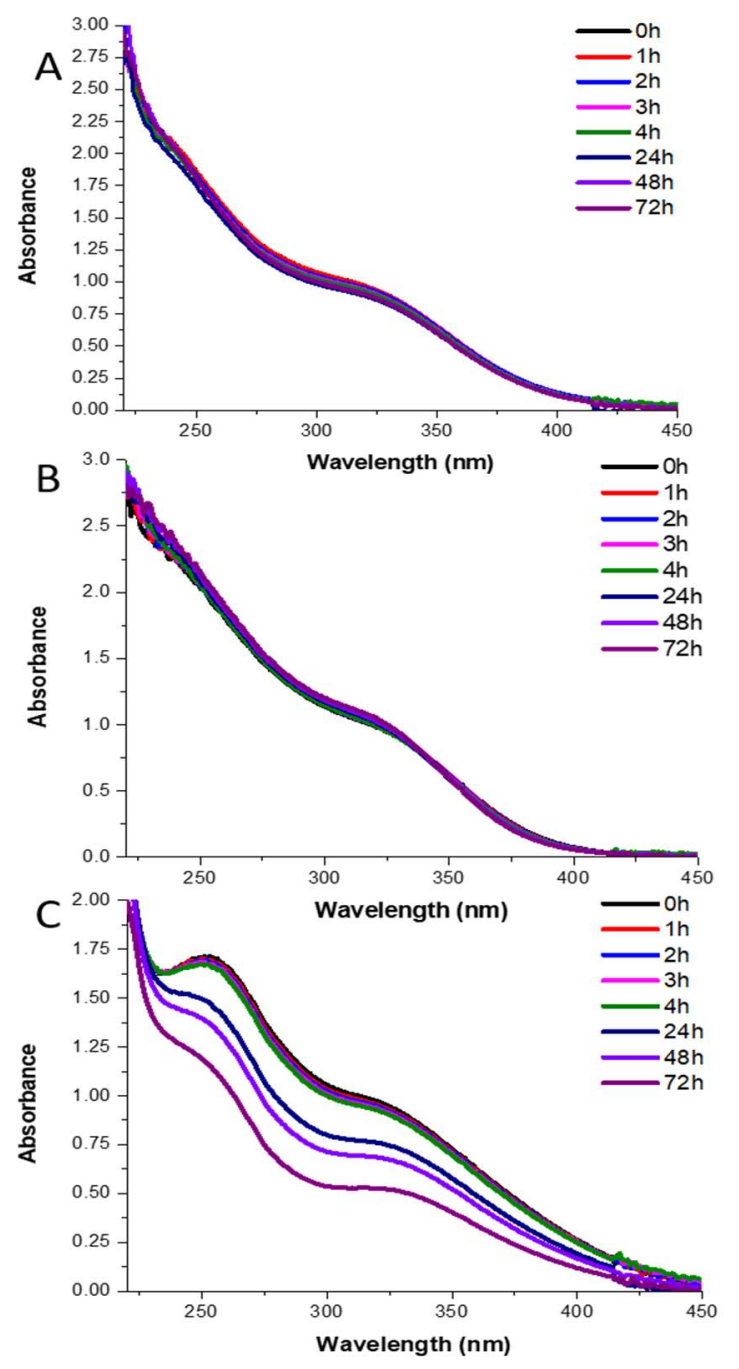

Figure S21. A) UV-vis spectra of $\mathrm{Fe}_{2}(\mathrm{PARA})$ were acquired over a $72 \mathrm{~h}$ time period at $37^{\circ} \mathrm{C}$. Solutions contained $200 \mathrm{uM} \mathrm{Fe}$ (PARA) and $10 \mathrm{mM}$ HEPES buffer at $7.2 \mathrm{pH}$. $\mathcal{E}(330 \mathrm{~nm})=4320$ $\mathrm{M}^{-1} \mathrm{~cm}^{-1}$. B) UV-vis spectra of $\mathrm{Fe}_{2}(\mathrm{PARA})$ were acquired over a $72 \mathrm{~h}$ time period at $37^{\circ} \mathrm{C}$. Solutions contained $200 \mathrm{uM} \mathrm{Fe}$ (PARA), $25 \mathrm{mM} \mathrm{NaHCO}_{3}, 0.50 \mathrm{mM} \mathrm{Na} 2 \mathrm{HPO}_{4}, 10 \mathrm{mM} \mathrm{HEPES}$ buffer at $7.2 \mathrm{pH} . \quad \varepsilon(330 \mathrm{~nm})=4540 \mathrm{M}^{-1} \mathrm{~cm}^{-1}$. C) UV-vis spectra of Fe2(PARA) were recorded over a $72 \mathrm{~h}$ time period at $37^{\circ} \mathrm{C}$. Solutions contained $200 \mathrm{uM} \mathrm{Fe}$ (PARA) dissolved in $0.1 \mathrm{M} \mathrm{HCl}$. $\varepsilon(250 \mathrm{~nm})=8450 \mathrm{M}^{-1} \mathrm{~cm}^{-1}, \varepsilon(330 \mathrm{~nm})=4500 \mathrm{M}^{-1} \mathrm{~cm}^{-1}$. 


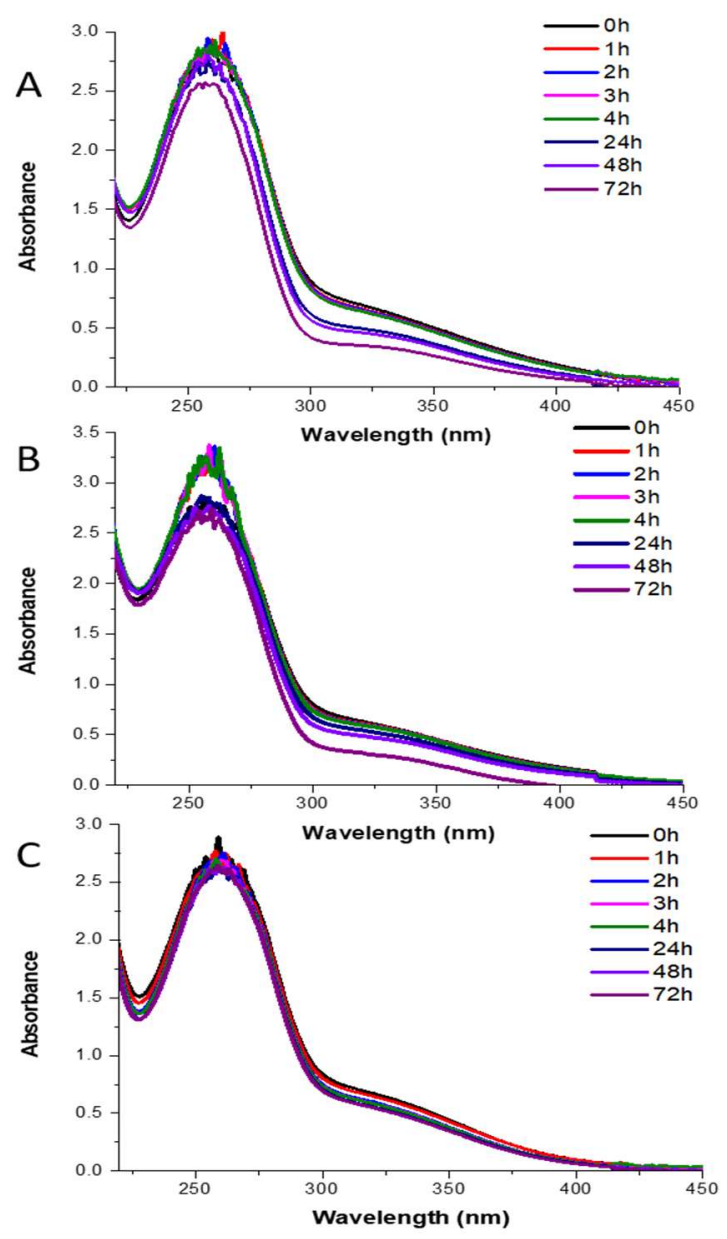

Figure S22. A) UV-vis spectra of $\mathrm{Fe}_{2}(\mathrm{DIP})$ were acquired over a $72 \mathrm{~h}$ time period at $37^{\circ} \mathrm{C}$. Solutions contained $200 \mathrm{uM} \mathrm{Fe}$ (DIP) and 10mM HEPES buffer at 7.2 pH. $\varepsilon(260 \mathrm{~nm})=14055 \mathrm{M}^{-}$ ${ }^{1} \mathrm{~cm}^{-1}, \varepsilon(330 \mathrm{~nm})=3100 \mathrm{M}^{-1} \mathrm{~cm}^{-1}$. Dissociation after $24 \mathrm{~h}$ was $25.5 \%$. Dissociation after $72 \mathrm{~h}$ was $45.6 \%$. B) UV-vis spectra of $\mathrm{Fe}_{2}(\mathrm{DIP})$ were acquired over a $72 \mathrm{~h}$ time period at $37^{\circ} \mathrm{C}$. Solutions contained $200 \mathrm{uM} \mathrm{Fe}$ (DIP), $25 \mathrm{mM} \mathrm{NaHCO}_{3}, 0.50 \mathrm{mM} \mathrm{Na}_{2} \mathrm{HPO}_{4}, 10 \mathrm{mM}$ HEPES buffer at 7.2 pH. . $\varepsilon(260 \mathrm{~nm})=16060 \mathrm{M}^{-1} \mathrm{~cm}^{-1}, \varepsilon(330 \mathrm{~nm})=2850 \mathrm{M}^{-1} \mathrm{~cm}^{-1}$. Dissociation after $24 \mathrm{~h}$ was $11.6 \%$. Dissociation after $72 \mathrm{~h}$ was $48.6 \%$. C) UV-vis spectra of $\mathrm{Fe}_{2}(\mathrm{DIP})$ were recorded over a $72 \mathrm{~h}$ time period at $37^{\circ} \mathrm{C}$. Solutions contained $200 \mathrm{uM} \mathrm{Fe}$ (DIP) dissolved in $0.1 \mathrm{M} \mathrm{HCl}$. $\mathcal{E}(260 \mathrm{~nm})=13450$ $\mathrm{M}^{-1} \mathrm{~cm}^{-1}, \varepsilon(330 \mathrm{~nm})=3030 \mathrm{M}^{-1} \mathrm{~cm}^{-1}$. 


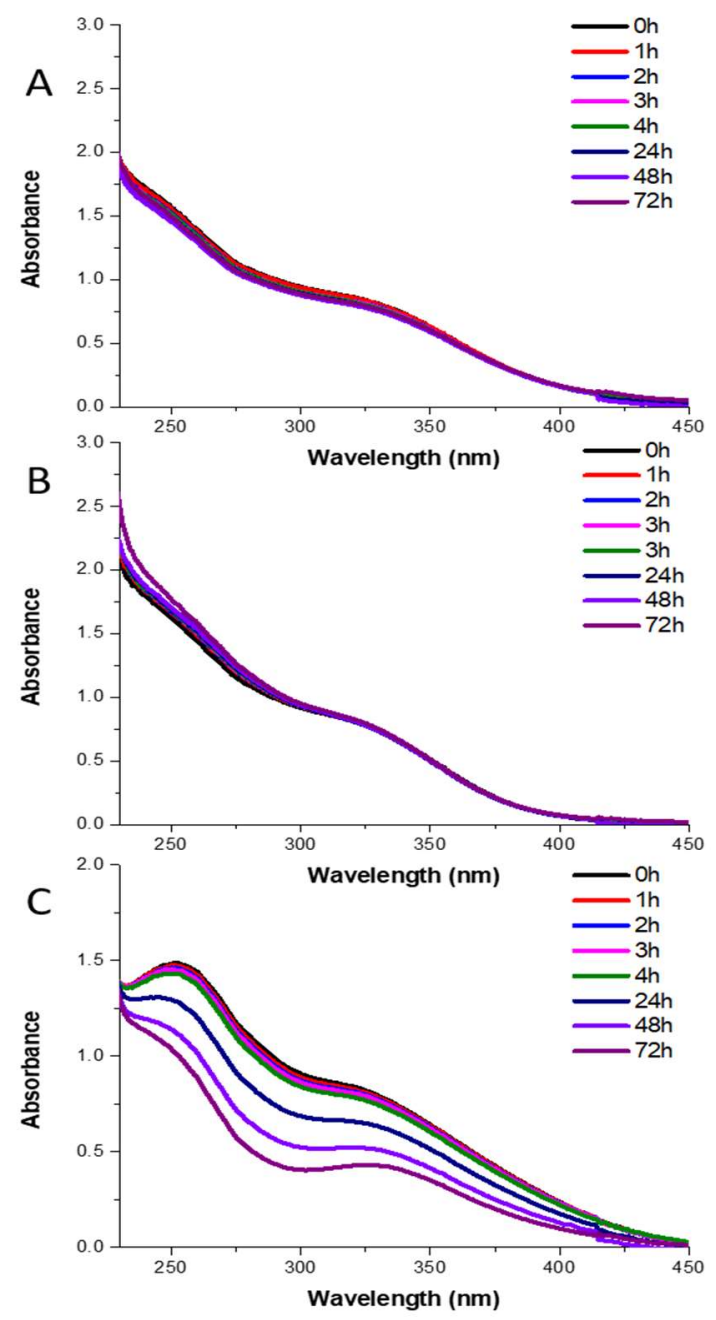

Figure S18. A) UV-vis spectra of Fe(TOLPO) were acquired over a $72 \mathrm{~h}$ time period at $37^{\circ} \mathrm{C}$. Solutions contained $200 \mathrm{uM} \mathrm{Fe}($ TOLPO) and $10 \mathrm{mM}$ HEPES buffer at $7.2 \mathrm{pH}$. $\mathcal{E}(250 \mathrm{~nm})=7750$ $\mathrm{M}^{-1} \mathrm{~cm}^{-1}, \varepsilon(330 \mathrm{~nm})=3935 \mathrm{M}^{-1} \mathrm{~cm}^{-1}$. B) UV-vis spectra of Fe(TOLPO) were acquired over a $72 \mathrm{~h}$ time period at $37^{\circ} \mathrm{C}$. Solutions contained $200 \mathrm{uM}$ Fe(TOLPO), $25 \mathrm{mM} \mathrm{NaHCO}, 0.50 \mathrm{mM}$ $\mathrm{Na}_{2} \mathrm{HPO}_{4}, 10 \mathrm{mM}$ HEPES buffer at $7.2 \mathrm{pH}$. $\varepsilon(330 \mathrm{~nm})=3720 \mathrm{M}^{-1} \mathrm{~cm}^{-1}$. C) UV-vis spectra of $\mathrm{Fe}(\mathrm{TOLPO})$ were recorded over a $72 \mathrm{~h}$ time period at $37^{\circ} \mathrm{C}$. Solutions contained $200 \mathrm{uM}$ Fe(TOLPO) dissolved in 0.1M HCl. $\varepsilon(250 \mathrm{~nm})=7325 \mathrm{M}^{-1} \mathrm{~cm}^{-1}, \varepsilon(330 \mathrm{~nm})=3900 \mathrm{M}^{-1} \mathrm{~cm}^{-1}$. 
Table S3. Percent iron complex dissociation or decomposition in $100 \mathrm{mM} \mathrm{HCl}$, monitored at 330 $\mathrm{nm}$, at $24 \mathrm{~h}$ and $72 \mathrm{~h}, 37^{\circ} \mathrm{C}$. * Data from reference 1 .

\begin{tabular}{ccc}
\hline Complex & $24 \mathrm{~h}(\%$ dissociation $)$ & $72 \mathrm{~h}(\%$ dissociation $)$ \\
\hline $\mathrm{Fe}(\mathrm{TOB})^{*}$ & 13.8 & 28.0 \\
$\mathrm{Fe}(\mathrm{TOLPO})$ & 18.3 & 45.4 \\
$\mathrm{Fe}_{2}(\mathrm{META})$ & 15.0 & 62.8 \\
$\mathrm{Fe}_{2}(\mathrm{PARA})$ & 20.1 & 43.6 \\
$\mathrm{Fe}_{2}$ (DIP) & 11.2 & 18.7 \\
\hline
\end{tabular}




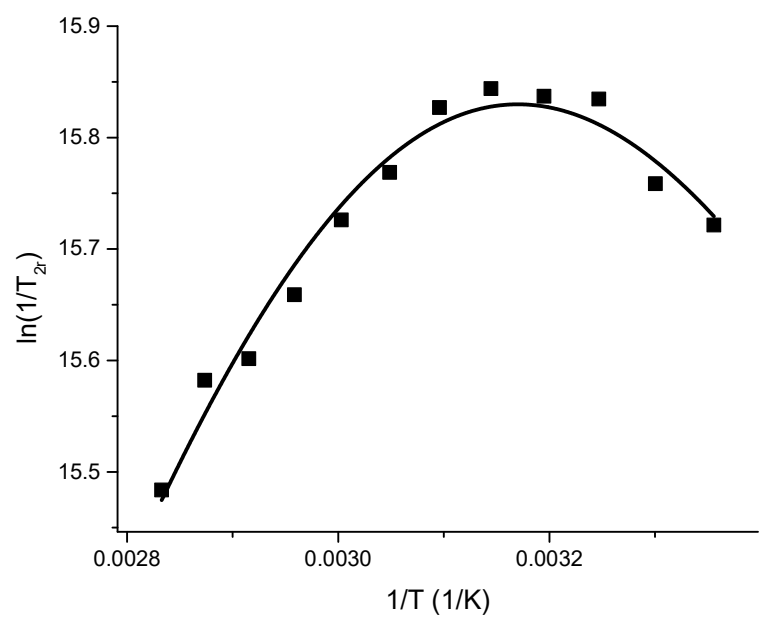

Figure S24. Variable temperature ${ }^{17} \mathrm{O}$ NMR data for Fe(CDTA) (4 mM by ICP-MS analysis of $\mathrm{Fe}$ ), at $\mathrm{pH}$ 6.6, $100 \mathrm{mM} \mathrm{NaCl}$. Data fit to the Swift-Connick equations ${ }^{2}$ to give $\mathrm{k}_{\mathrm{ex}}$ of $3.2 \times 10^{7} \mathrm{~s}^{-1}$. This result is similar to that reported by Van Eldik, ${ }^{3}$ although conditions in this earlier publication differ from those here (20 $\mathrm{mM}$ and $\mathrm{pH}$ of 4 to 5$)$.

The transverse relaxation time of ${ }^{17} \mathrm{O}$ was measured through the half line width of the $\mathrm{H}_{2}{ }^{17} \mathrm{O}$ NMR signal at half height at variable temperatures $\left(20-80{ }^{\circ} \mathrm{C}\right)$.

$$
\frac{1}{T_{2 r}}=\frac{\pi}{P_{m}} *\left(\Delta v_{\text {observed }}-\Delta v_{\text {solvent }}\right)=\frac{1}{\tau_{m}} * \frac{\left(T_{2 m}^{-1}+T_{2 m}^{-1} * \tau_{m}^{-1}+\Delta \omega_{m}^{2}\right)}{\left(T_{2 m}^{-1}+\tau_{m}^{-1}\right)^{2}+\Delta \omega_{m}^{2}}+\frac{1}{T_{2 o s}}
$$

In Eq., $\frac{1}{\mathrm{~T}_{2 \mathrm{r}}}$ is the reduced transverse relaxation rate, $\mathrm{P}_{\mathrm{m}}$ is the molar fraction of bound water, ( $\left.\Delta v_{\text {observed }}-\Delta v_{\text {solvent }}\right)$ is the difference in half line widths with and without complex, $\frac{1}{\tau_{m}}$ is the residence time of the bound water molecules, $\mathrm{T}_{2 \mathrm{~m}}^{-1}$ is the transverse relaxation rate of the bound water, and $\Delta \omega_{\mathrm{m}}$ is the chemical shift difference between bound and bulk water. $\frac{1}{\mathrm{~T}_{2 \mathrm{os}}}$ represents the transverse relaxation. At low temperature ranges, $\mathrm{T}_{2 \mathrm{~m}}^{-1}$ and $\frac{1}{\mathrm{~T}_{2 \mathrm{os}}}$ can be neglected and the SwiftConnick equation can be shown as a simple representation (Equation S2). ${ }^{2}$

Eq. S2

$$
\frac{1}{T_{2 r}}=\frac{\pi}{P_{m}} *\left(\Delta v_{\text {observed }}-\Delta v_{\text {solvent }}\right)=\frac{1}{\tau_{m}} * \frac{\Delta \omega_{m}^{2}}{\tau_{m}{ }^{-2}+\Delta \omega_{m}^{2}}
$$

Eq. S3

$$
\frac{1}{\tau_{m}}=k_{e x}
$$

Water exchange rate constants $\left(\mathrm{k}_{\mathrm{ex}}\right)$ are equal to $\frac{1}{\tau_{\mathrm{m}}}$ (Eq.). The $\mathrm{k}_{\mathrm{ex}}$ value at $298 \mathrm{~K}$ in this study was calculated by fitting the data to the equations by using the Scientist program and Micromath program. 


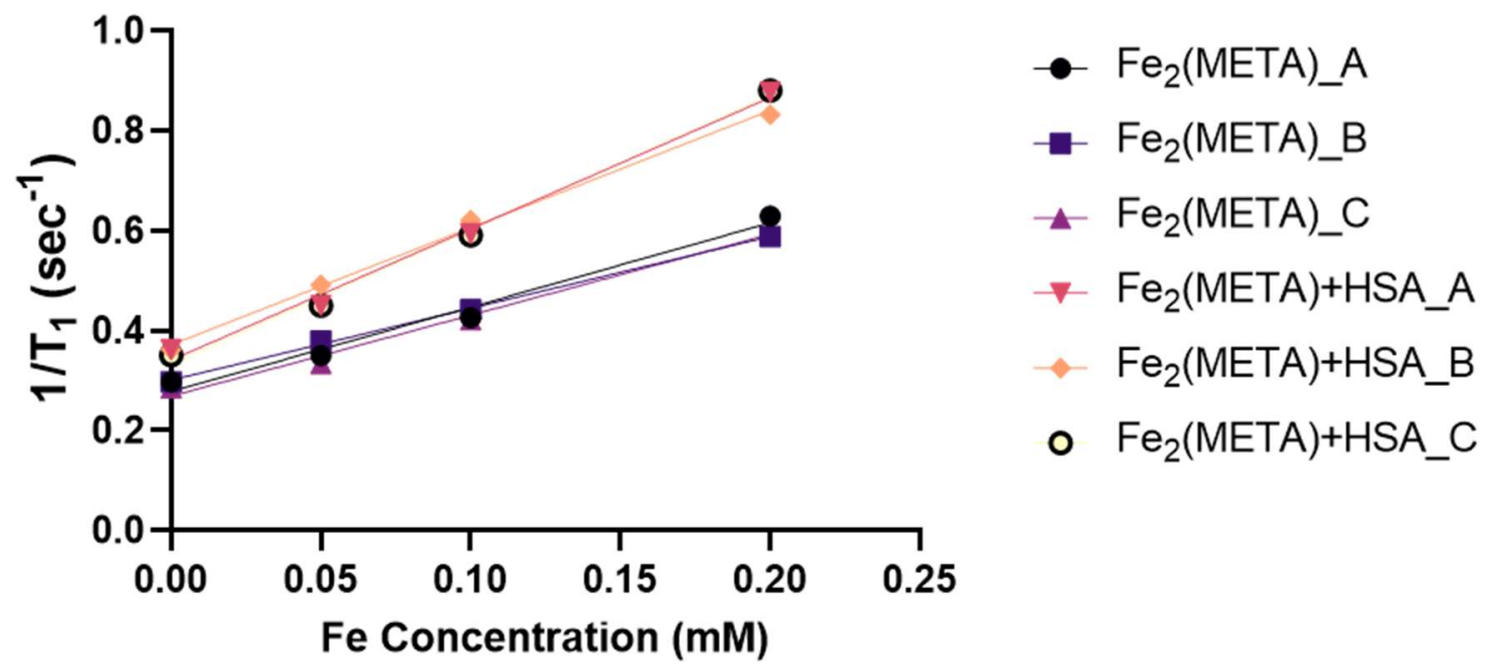

Figure S25. $1 / \mathrm{T}_{1}\left(\mathrm{sec}^{-1}\right)$ values of $\mathrm{Fe}_{2}(\mathrm{META})$ and $\mathrm{Fe}_{2}(\mathrm{META})$ with $\mathrm{HSA}$ at $4.7 \mathrm{~T}(\mathrm{pH} 7.2$ and 37 $\left.{ }^{\circ} \mathrm{C}\right)$ as a function of iron concentration $(\mathrm{mM})$. The $\mathrm{r}_{1}$ relaxivity of $\mathrm{Fe}_{2}(\mathrm{META})$ is $4.1\left(\mathrm{mM}^{-1} \cdot \mathrm{sec}^{-}\right.$ $\left.{ }^{1}\right)$, $\mathrm{r}_{1}$ relaxivity of $\mathrm{Fe}_{2}$ (META) with HSA is $6.6\left(\mathrm{mM}^{-1} \cdot \mathrm{sec}^{-1}\right)$.

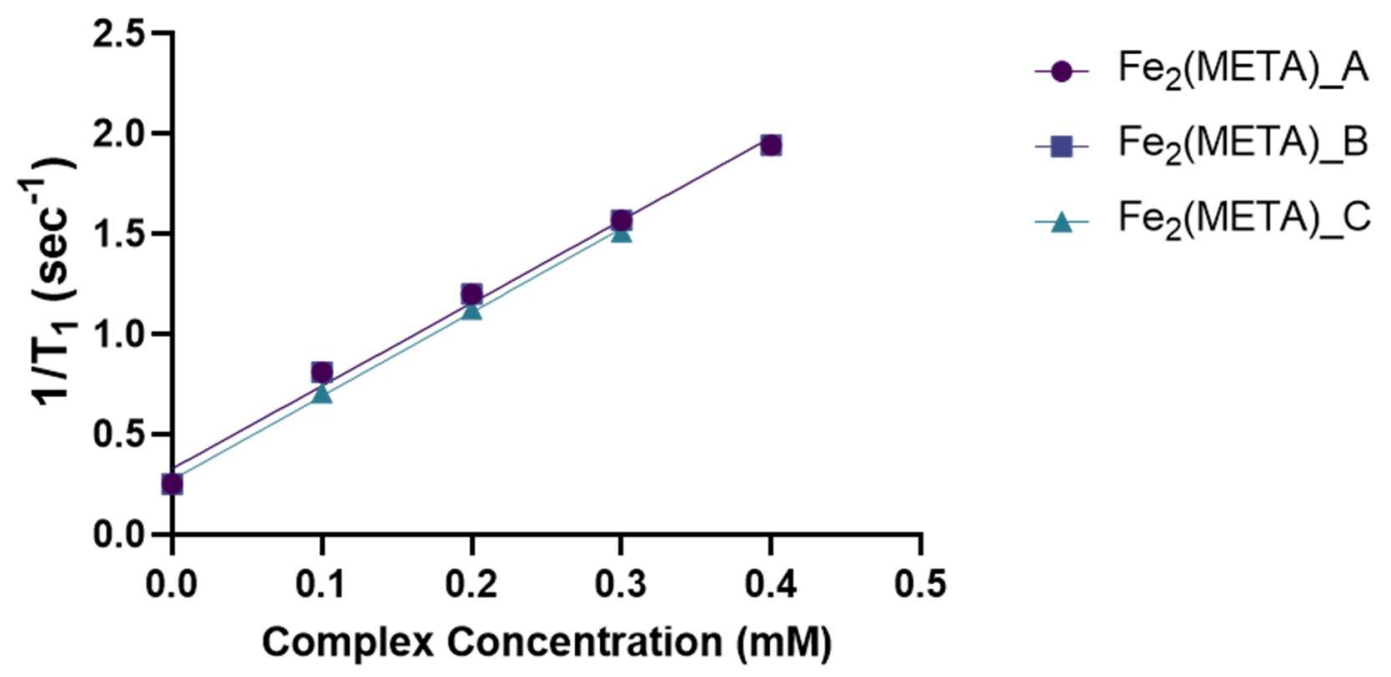

Figure S26. $1 / \mathrm{T}_{1}\left(\mathrm{sec}^{-1}\right)$ values of $\mathrm{Fe}_{2}(\mathrm{META})$ at $9.4 \mathrm{~T}\left(\mathrm{pH} 7.2\right.$ and $\left.37^{\circ} \mathrm{C}\right)$ as a function of the complex concentration $(\mathrm{mM})$. The $\mathrm{r}_{1}$ relaxivity of $\mathrm{Fe}_{2}(\mathrm{META})$ is $4.15\left(\mathrm{mM}^{-1} \cdot \mathrm{sec}^{-1}\right)$. 


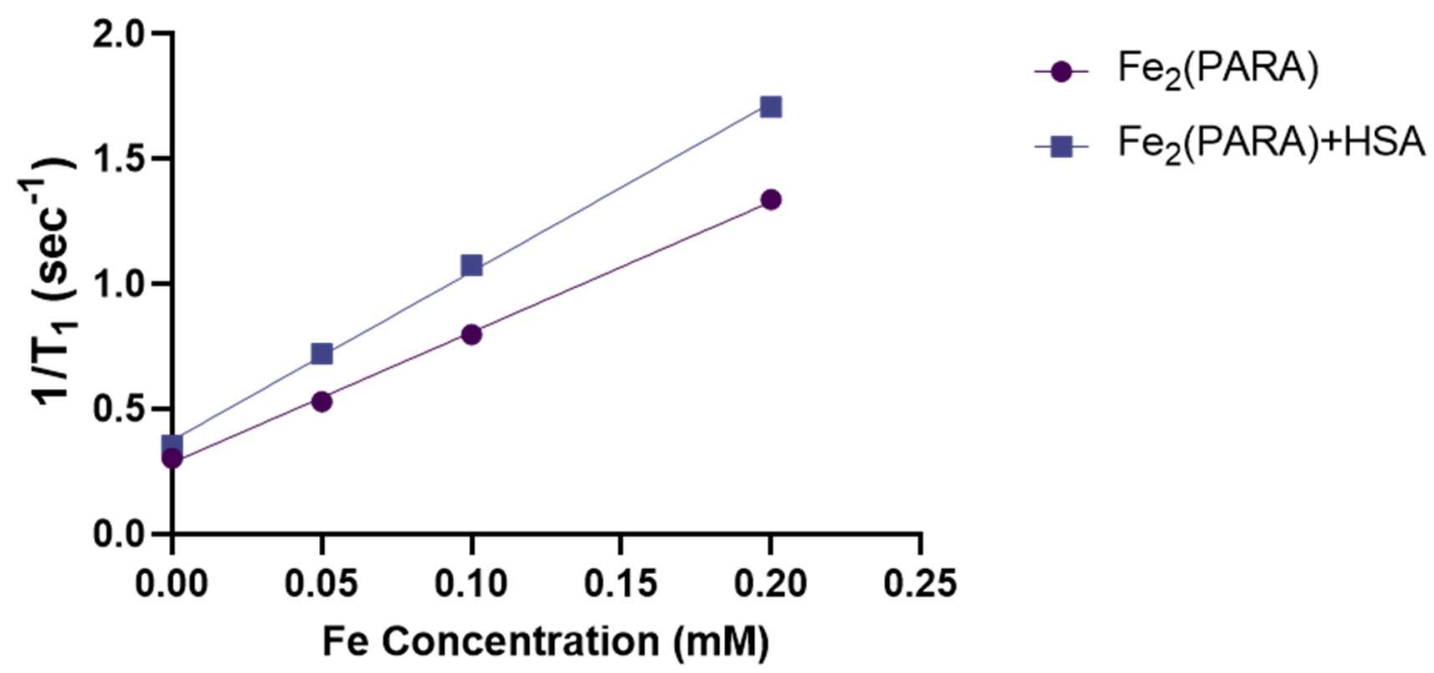

Figure S27. 1/ $\mathrm{T}_{1}\left(\mathrm{sec}^{-1}\right)$ values of $\mathrm{Fe}_{2}(\mathrm{PARA})$ at $4.7 \mathrm{~T}\left(\mathrm{pH} 7.2\right.$ and $\left.37^{\circ} \mathrm{C}\right)$ as a function of iron concentration $(\mathrm{mM})$. The $\mathrm{r}_{1}$ relaxivity of $\mathrm{Fe}_{2}(\mathrm{PARA})$ is $5.22\left(\mathrm{mM}^{-1} \mathrm{~s}^{-1}\right)$ and with HSA the relaxivity is $6.68 \mathrm{mM}^{-1} \mathrm{~s}^{-1}$.

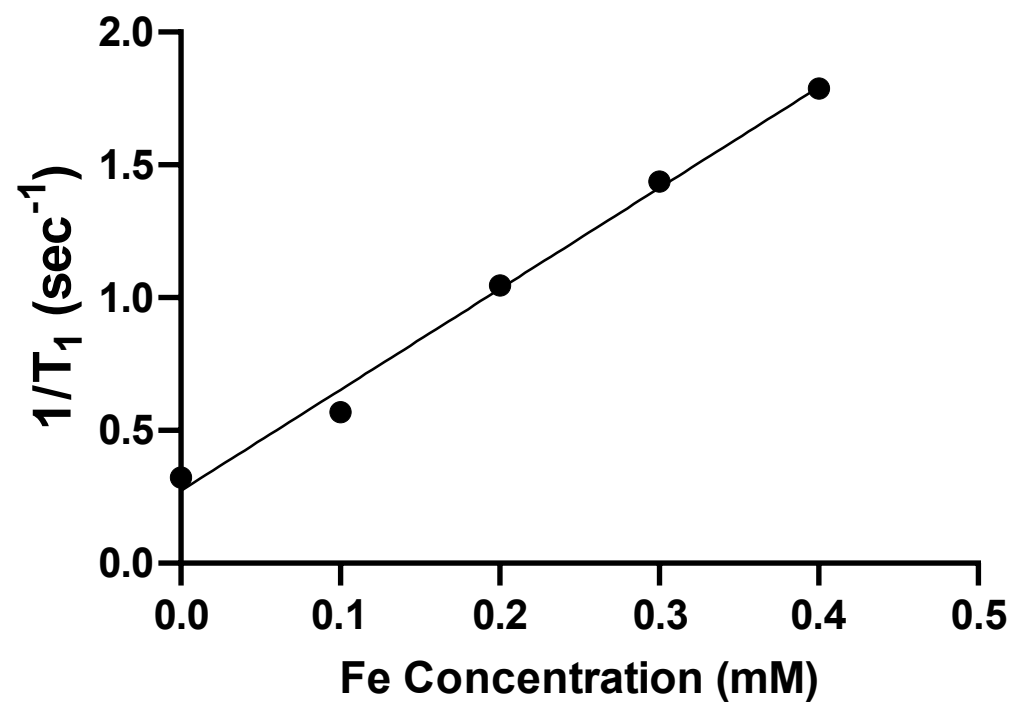

Figure S28. $1 / \mathrm{T}_{1}\left(\mathrm{sec}^{-1}\right)$ values of $\mathrm{Fe}_{2}(\mathrm{DIP})$ at $9.4 \mathrm{~T}\left(\mathrm{pH} 7.2\right.$ and $\left.37{ }^{\circ} \mathrm{C}\right)$ as a function of the complex concentration $(\mathrm{mM})$. The $\mathrm{r}_{1}$ relaxivity of $\mathrm{Fe}_{2}(\mathrm{DIP})$ is $5.57\left(\mathrm{mM}^{-1} \mathrm{sec}^{-1}\right)$. 


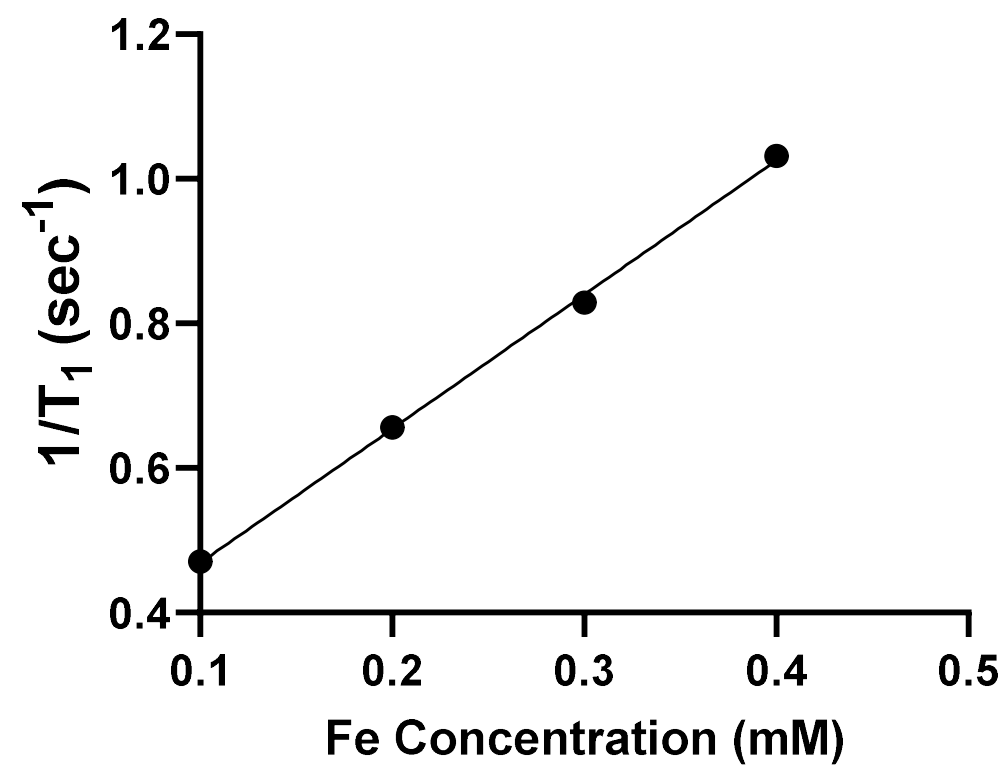

Figure S29. $1 / \mathrm{T}_{1}\left(\mathrm{sec}^{-1}\right)$ values of $\mathrm{Fe}_{2}(\mathrm{DIP})$ at $1.4 \mathrm{~T}\left(\mathrm{pH} 7.2\right.$ and $\left.37^{\circ} \mathrm{C}\right)$ as a function of the complex concentration (mM). $\mathrm{r}_{1}$ relaxivity of $\mathrm{Fe}_{2}(\mathrm{DIP})$ is $3.38\left(\mathrm{mM}^{-1} \mathrm{sec}^{-1}\right)$. 

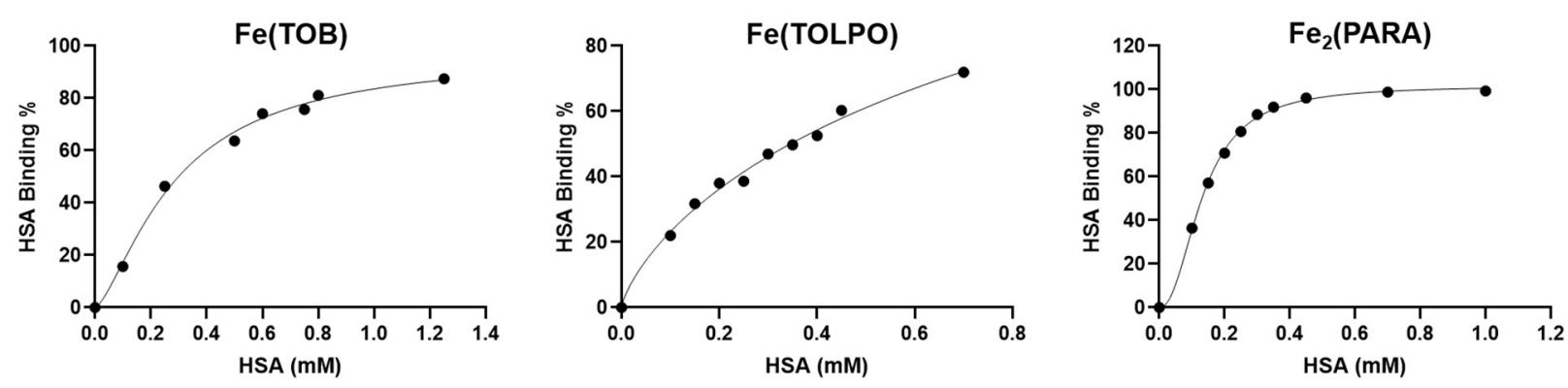

Figure S30. The HSA binding isotherms for $\mathrm{Fe}(\mathrm{TOB}), \mathrm{Fe}(\mathrm{TOLPO})$ and $\mathrm{Fe}_{2}(\mathrm{PARA})$ at $0.40 \mathrm{mM}$, $\mathrm{pH} 7.2$ in HEPES, $37^{\circ} \mathrm{C}$. The solid line is the best fit by using Hill binding equation as given in manuscript (Eq. 5).

Table S4. Equilibrium constants $\left(\mathrm{K}_{\mathrm{a}}\right)$ values of the stoichiometric binding fit, $\mathrm{n}$ values calculated from Hill equation isotherm and $r$ squared values of the best fits to data in Figure S30.

\begin{tabular}{cccc}
\hline Complex & n (Hill Slope) & $\mathbf{K}_{\mathbf{a}}$ & $\mathbf{R}^{\mathbf{2}}$ \\
\hline $\mathrm{Fe}(\mathrm{TOB})$ & 1.5 & $3.4 \times 10^{3}$ & 0.9954 \\
$\mathrm{Fe}(\mathrm{TOLPO})$ & 0.76 & $7.1 \times 10^{2}$ & 0.9933 \\
$\mathrm{Fe}_{2}(\mathrm{PARA})$ & 2.2 & $1.4 \times 10^{4}$ & 0.9990 \\
\hline
\end{tabular}




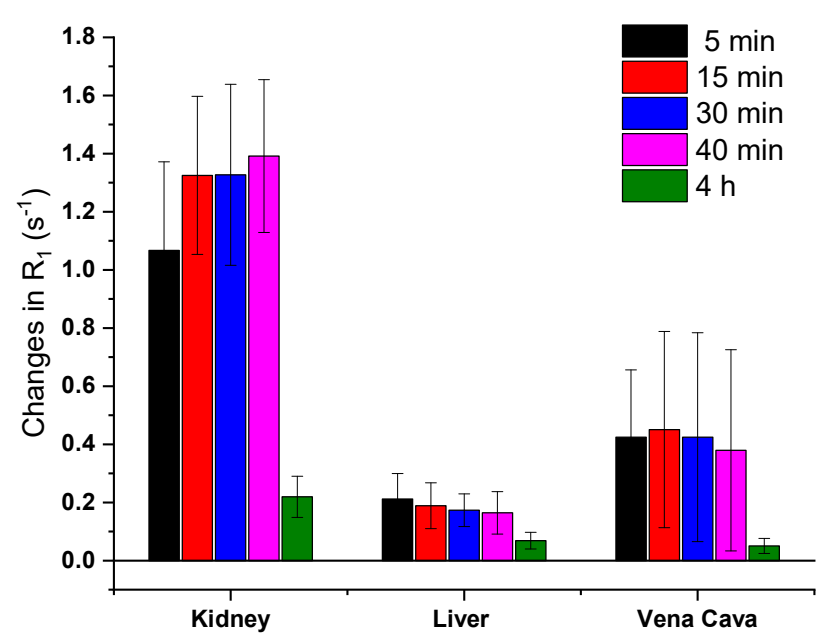

Figure S31. Change in $\mathrm{R}_{1}$ rate constants for proton relaxation in mice treated with $\mathrm{Fe}_{2}(\mathrm{PARA})$ at $0.025 \mathrm{mmol} / \mathrm{kg}$ over time in the kidneys, liver and inferior vena cava in healthy Balb/C mice at 4.7

T. Data at 4 hours is included in these bar graphs.
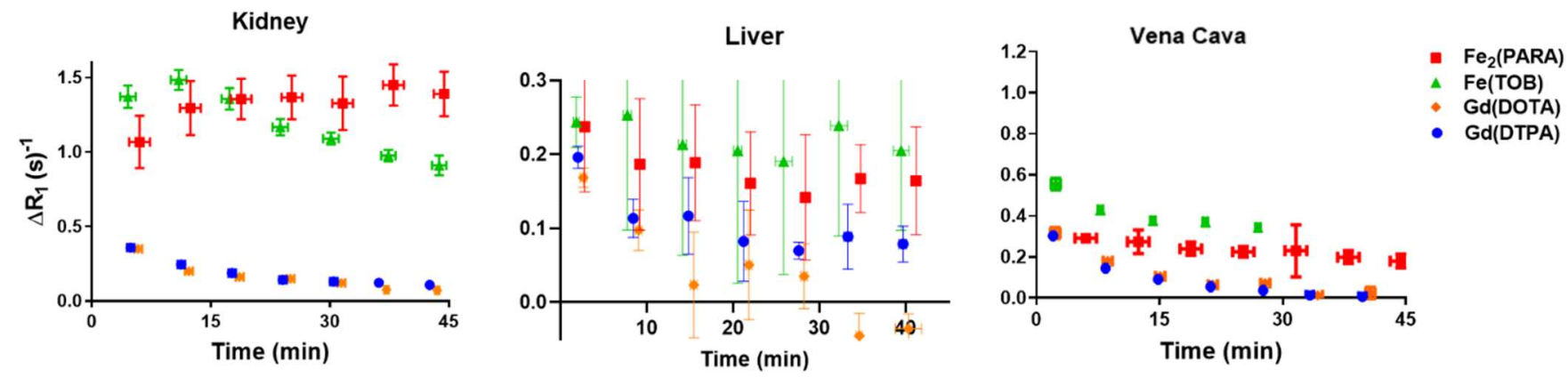

Figure S32. Change in $\mathrm{R}_{1}$ rate constants in mice for $\mathrm{Fe}_{2}(\mathrm{PARA})$ at $0.025 \mathrm{mmol} / \mathrm{kg}$ dose; $\mathrm{Fe}(\mathrm{TOB}), \mathrm{Gd}(\mathrm{DTPA})$ and $\mathrm{Gd}(\mathrm{DOTA})$ at a $0.050 \mathrm{mmol} / \mathrm{kg}$ dose over time in the kidneys, in liver and inferior vena cava in healthy Balb/C mice at $4.7 \mathrm{~T}$. 
Scheme S.1. Chemical structures of the Fe(III) species detected by LC-MS, and FT-ICR-MS in methanol/water solvent mixture.

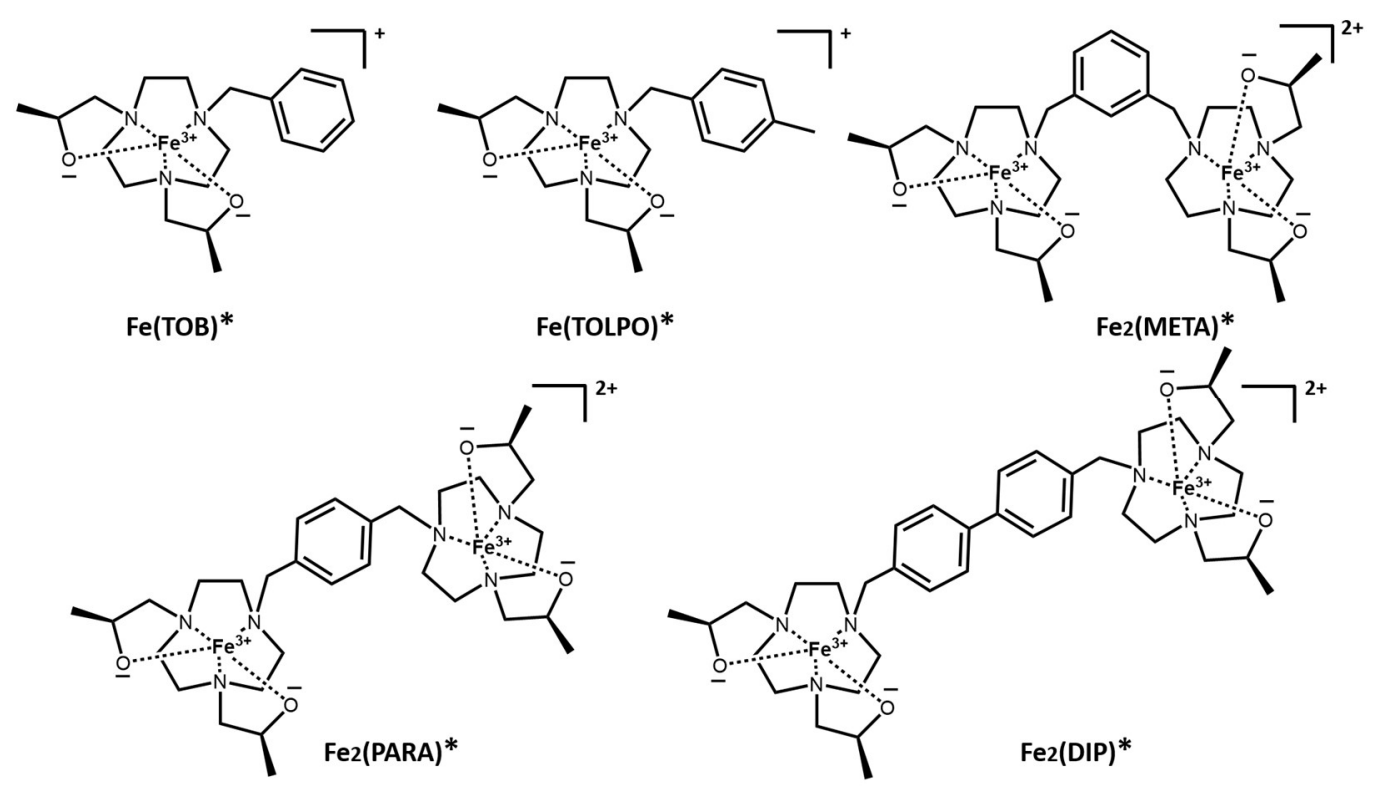

\section{References.}

1. $\quad$ Snyder, E. M.; Asik, D.; Abozeid, S. M.; Burgio, A.; Bateman, G.; Turowski, S. G.; Spernyak, J. A.; Morrow, J. R., A Class of Fe ${ }^{\mathrm{III}}$ Macrocyclic Complexes with Alcohol Donor Groups as Effective T1 MRI Contrast Agents. Angew. Chem. Int. Ed. 2020, 132 (6), 2435-2440.

2. $\quad$ Abozeid, S. M.; Snyder, E. M.; Tittiris, T. Y.; Steuerwald, C.M.; Nazarenko, A. Y.; Morrow, J. R., "Co(II) complexes with innersphere and outersphere water interactions for CEST MRI applications" Inorg. Chem. 2018, 57, 2085-2095.

3. Schneppensieper, T; Seibig, S., Zahl, A.; Tregloann, P.; van Eldik, R. " Influence of Chelate Effects on the Water-Exchange Mechanism of Polyaminecarboxylate Complexes of Iron(III)" Inorg. Chem. 2001, 40, 3670-3676.

4. $\quad$ Brausam, A.; Maigut, J.; Meier. R.; Szilagyi. P. A.; Buschmann, H.-J. Massa, W.; Homonna, Z.; van Eldik, R. " Detailed Spectroscopic, Thermodynamic, and Kinetic Studies on the Protolytic Equilibria of FeIIIcydta and the Activation of Hydrogen Peroxide" Inorg. Chem. 2009, 48, 7864-7884. 